San Jose State University

SJSU ScholarWorks

Master's Theses

Master's Theses and Graduate Research

1996

\title{
Trace element and organochlorine compounds in harbor seals (Phoca vitulina richardsi) along the Pacific Coast
}

Doreen Grace Moser

San Jose State University

Follow this and additional works at: https://scholarworks.sjsu.edu/etd_theses

\section{Recommended Citation}

Moser, Doreen Grace, "Trace element and organochlorine compounds in harbor seals (Phoca vitulina richardsi) along the Pacific Coast" (1996). Master's Theses. 1247.

DOI: https://doi.org/10.31979/etd.xfjy-4mpp

https://scholarworks.sjsu.edu/etd_theses/1247

This Thesis is brought to you for free and open access by the Master's Theses and Graduate Research at SJSU ScholarWorks. It has been accepted for inclusion in Master's Theses by an authorized administrator of SJSU ScholarWorks. For more information, please contact scholarworks@sjsu.edu. 


\section{INFORMATION TO USERS}

This manuscript has been reproduced from the microfilm master. UMI films the text directly from the original or copy submitted. Thus, some thesis and dissertation copies are in typewriter face, while others may be from any type of computer printer.

The quality of this reproduction is dependent upon the quality of the copy submitted. Broken or indistinct print, colored or poor quality illustrations and photographs, print bleedthrough, substandard margins, and improper alignment can adversely affect reproduction.

In the unlikely event that the author did not send UMI a complete manuscript and there are missing pages, these will be noted. Also, if unauthorized copyright material had to be removed, a note will indicate the deletion.

Oversize materials (e.g., maps, drawings, charts) are reproduced by sectioning the original, beginning at the upper left-hand corner and continuing from left to right in equal sections with small overlaps. Each original is also photographed in one exposure and is included in reduced form at the back of the book.

Photographs included in the original manuscript have been reproduced xerographically in this copy. Higher quality 6" $\mathrm{x} 9$ " black and white photographic prints are available for any photographs or illustrations appearing in this copy for an additional charge. Contact UMI directly to order.

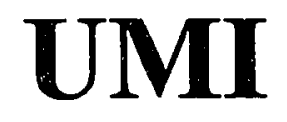

A Bell \& Howell Information Company 



\title{
TRACE ELEMENT AND ORGANOCHLORINE COMPOUNDS IN HARBOR SEALS (Phoca vitulina richards!) ALONG THE PACIFIC COAST
}

\author{
A Thesis \\ Presented to \\ The Faculty of Moss Landing Marine Laboratories \\ San Jose State University \\ In Partial Fulfillment \\ of the Requirements for the Degree \\ Master of Science
}

by

Doreen Grace Moser

May 1996 
UMI Number: 1379362

UMI Microform 1379362

Copyright 1996, by UMI Company. All rights reserved.

This microform edition is protected against unguthorized copying under Title 17, United States Code.

\section{UMI \\ 300 North Zeeb Road \\ Ann Arbor, MI 48103}


(C) 1996

Doreen Grace Moser

\section{ALL RIGHTS RESERVED}


APPROVED FOR THE DEPARTMENT OF

MOSS LANDING MARINE LABORATORIES

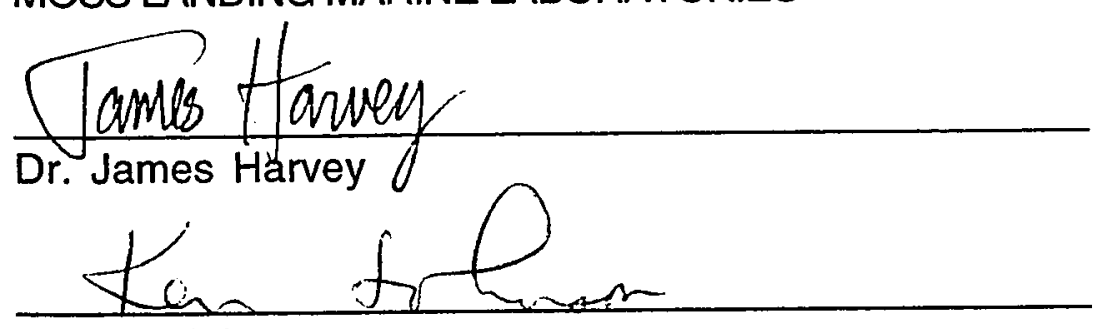

Dr. Ken Johnson

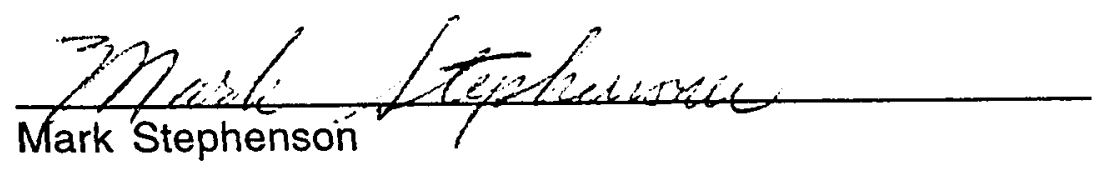

APPROVED FOR THE UNIVERSITY

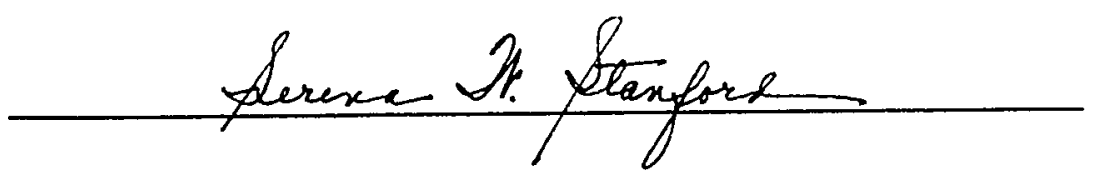




\begin{abstract}
TRACE ELEMENT AND ORGANOCHLORINE COMPOUNDS IN HARBOR SEALS (Phoca vitulina richardsi) ALONG THE PACIFIC COAST
\end{abstract}

by Doreen Grace Moser

Contaminant levels of harbor seals were compared from Elkhorn Slough, California to other areas with greater pupping rates. Blood, blubber, and hair samples were collected from seals in Elkhorn Slough, Channel Islands, CA; Umpqua River, OR; and Grays Harbor, WA. There was no significant difference among sites in blood concentrations of DDE (19 $\pm 14 \mathrm{ng} / \mathrm{g}, \mathrm{p}=0.05)$ or PCB $1254(196 \pm 244 \mathrm{ng} / \mathrm{g}, \mathrm{p}=0.19)$. Concentrations of DDE $(3000 \pm 2700 \mathrm{ng} / \mathrm{g})$ and PCB $1254(5600 \pm 5100 \mathrm{ng} / \mathrm{g})$ were greater in blubber. There was no significant difference among sites in blood concentrations of $\mathrm{Cu}(3.3 \pm 0.84 \mu \mathrm{g} / \mathrm{g}, \mathrm{p}=0.95)$, $\mathrm{Fe}(3100 \pm 1000 \mu \mathrm{g} / \mathrm{g}, \mathrm{p}=0.95)$, Se $(3.9 \pm 1.2 \mu \mathrm{g} / \mathrm{g}, \mathrm{p}=0.5)$, and $\mathrm{Zn}(29 \pm 6.7$ $\mu \mathrm{g} / \mathrm{g}, \mathrm{p}=0.98$ ). Contaminant levels were relatively low among areas, therefore, may not attribute to low reproductive rates in Elkhorn Slough.

Hair, liver, and muscle samples were collected from red and normalpelaged seals from San Francisco Bay. Hair samples from red and normalpelaged seals had similar $\mathrm{Fe}$ concentrations $(1800 \pm 1100 \mu \mathrm{g} / \mathrm{g}, \mathrm{p}=0.34)$. Hair samples had similar elemental composition. Red hairs had irregular cuticle scaling. Red pelage may result from a difference in hair structure, which allows elements to adhere. 


\section{ACKNOWLEDGMENTS}

I would first like to thank my commithee members: Dr. James T. Harvey of MLML, Dr. Ken Johnson of MLML, and Mark Stephenson of the California Department of Fish and Game(CDFG). Jim, my advisor, provided assistance throughout my project, from my first proposal, to collecting samples, to editing my thesis. Ken shared his knowledge of toxicology and gave me a strong chemical perspective. Mark funded the majority of this project through grants, equipment use, and employment at Mussel Watch.

Toxicology studies can be expensive; however, I was able to obtain funds through the following organizations: State Water Resource Control Board, CDFG Earl and Ethel Meyers Foundation, American Cetacean Society, California Sea Grant, Packard Foundation, and the Ray Cannon Scholarship.

Harbor seal samples can be difficult to obtain; however, I was assisted by the following people. Dianne Kopec and Bob Jones of UC Berkeley provided red pelage samples. Dianne also provided numerous references and genuine enthusiasm. Brent Stewart of Hubbs Research Institute obtained samples from the Channel Islands. Stephen Jeffries of Washington Department of Wildlife allowed me to tag along on his harbor seal captures to obtain samples. Krista Hanni and Dr. Kimberlee Beckman of The Marine Mammal Center provided hair samples and sampling supplies. Furthermore, The Center has provided me with a rewarding career in marine science education. Jeff Rash of the Washington marine mammal center provided hair samples. Tagging Gypsies and Moss Landing Slough Stompers (mainly Tony Orr, Tomo Eguchi, and Meg Lamont) provided spirit and support on our tagging expeditions. 
Chemical analysis can be complicated; however, many people provided their expertise and understanding. Employees of the Mussel Watch program provided hours of support with trace element analysis. Jon Goetzl taught me how to analyze samples on the fuinace AA. Jim Kanihan shared his knowledge of the flame AA and sample analysis. Kim Paulson and Gary Ichikawa also assisted with mercury analysis. Blubber samples were analyzed at the Trace organics Lab at Long Marine Lab, University of Santa Cruz. Jocelyn Vedder analyzed the samples. John Newman interpreted the results and provided his enthusiasm for trace organics. Furthermore, Dr. Wally Jarman reviewed my thesis. Bob Hose and Tom Lui of the Department of Fish and Game, NiMBUS lab analyzed blood samples for organochlorines. Sara Tanner of MLML analyzed hair samples on the SEM and provided photos. Bob Envin of Princeton Gamma Tech examined hair samples with the X-ray SEM. People in the Chemical Oceanography Lab at MLML provided their chemical knowledge.

I also need to thank numerous MLML staff. In administration, Gail Johnston and Sandy Yarbourough assisted with paper work and deadlines. Librarian Shelia Baldridge and Joan Parker obtained the most obscure references. Lynn McMasters assisted with computer graphics.

Students at MLML provided friendship and support during my four years. Cheryl Baduini and Dion Oxman edited my thesis. Cheryl and other roommates: Debbie Nebenzahl, Trishia Lowe, and Linda Browne provided a wonderful environment in which to study and play. In addition other friends and Ultimate players provided hours of distractions and allowed me to enjoy my time at MLML. Finally, I would like to thank my family, who have always supported me in all my endeavors. 


\section{TABLE OF CONTENTS}

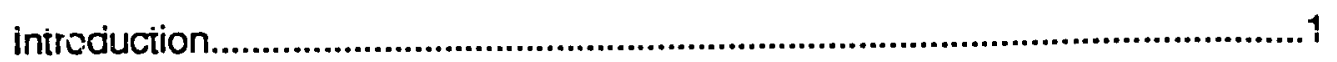

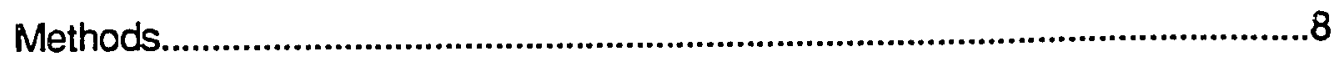

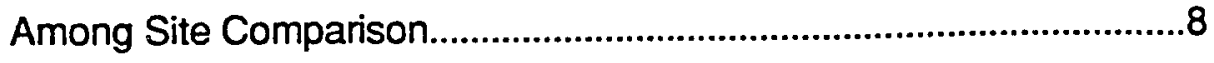

Sample Collection..........................................................................

Organochlorine Analysis..............................................................

Trace Element Analysis..........................................................12

Red Pelage Comparison...................................................................14

Sample Collection......................................................................14

Trace Element Analysis...........................................................15

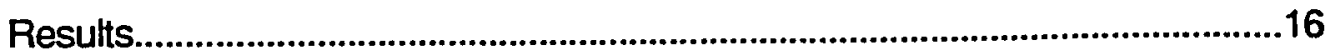

Among Site Comparison.................................................................16

Organochlorine Analysis.........................................................16

Trace Element Analysis...........................................................18

Red Pelage Comparison...............................................................21

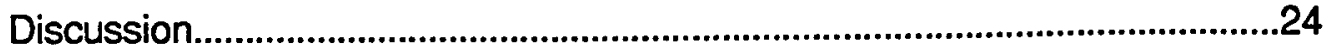

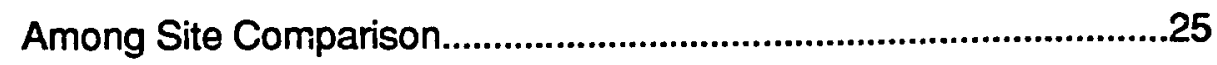

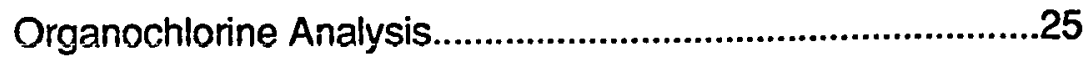

Trace Element Analysis.........................................................28

Red Polage Comparison......................................................................31

Literature Cited..................................................................................................34

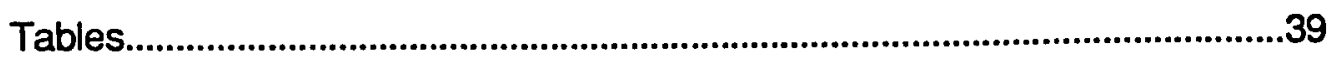

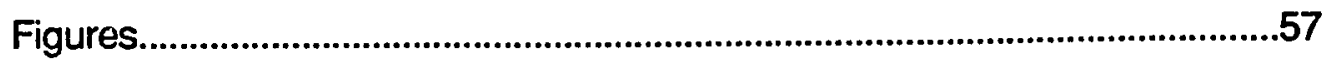




\section{INTRODUCTION}

Contaminants from natural and anthropogenic sources (e.g. metals, oil, and organic compounds) occur in marine ecosysiems. Miarine contaminant levels may increase along coastal and in estuarine ecosystems near anthropogenic sources (Phillips 1980, Aguilar 1987). Contaminants may first accumulate in sediment, then are taken up by infauna. In turn, infauna may be consumed by higher trophic organisms, mainly fishes, birds, and mammals. Organochlorines, such as dichlorodiphenyltrichlorethane (DDT) and polychlorinated biphenyls (PCBs), are introduced into marine ecosystems as non-point source contaminants, via river run-off, industrial effluents, atmosphere, and sewage (Aguilar 1987, Phillips 1980). These compounds can be transferred through the food chain. As a result, these organochlorine compounds accumulate in body tissues of higher vertebrates (Shaw and Connell 1982; Aguilar 1984). Many organochlorine compounds are lipophilic and accumulate in fatty tissues. Bioaccumulation of organochlorine compounds provides an opportunity to measure contaminants in higher trophic levels, which often are undetectable in sediment and other biota. Trace elements are not stored in fat tissue, and may not bioaccumulate in tissues of higher vertebrates (Michaels and Flegal 1990). Instead, the animal may metabolize elements.

Because pinnipeds occur at the top of the food chain and inhabit polluted coastal areas, researchers have reported elevated contaminant concentrations in pinnipeds compared to their prey (Reijnders 1980, Calambokidis et al. 1984, Wagemann 1989, Wenzel et al. 1993, Szefer et al. 1994). Risebrough (1978) stated that the greatest contaminant levels in pinnipeds were found in blubber of harbor seals (Phoca vitulina). 
Pinniped contaminant levels vary with age, sex, parturition, stress, and geographic range (Aguilar 1987, Reijnders 1988). Organochlorine compounds mobilize from fatty tissues into the blood stream during pregnancy, iaciation, stress, and starvation. Organochlorine compounds may weaken the immune system or a suppressed immune system may cause mobilization of pesticides (Britt and Howard 1983). Contaminants are transferred to offspring during parturition and lactation; therefore, newborn pups can have elevated pollutant concentrations (Aguilar 1987, Reijnders 1988). Female contaminant loads will decrease during parturition, whereas male contaminant loads may increase with age. During starvation, blubber decreases and organochlorines are forced into blood circulation and other tissues (Reijnders 1988). Marine mammals that feed in contaminated areas accumulate contaminants; therefore, contaminant levels in harbor seals may vary geographically (Reijnders 1988).

Researchers speculated that sublethal concentrations of pollutants have caused immunosuppression and reproductive disorders in many vertebrates. Freeman et al. (1980) stated that certain organochlorines, such as PCBs and DDT, could have affected enzymes that control steroid metabolism, which ultimately may have suppressed an organism's immune and reproductive systems. These organochlorines have a similar molecular structure to steroids and may have caused an increase in steroid metabolization, which decreased circulation of sex hormones and certain vitamins (Britt and Howard 1983). In pinnipeds, elevated DDT and PCB levels were correlated with increased mortality, lesser reproductive rates, and pathological disorders (Helle et al. 1976, Reijnders 1980, Calambokidis et al. 1984. Hyvarinen and Sipila 1984, Subramanian et al. 1987; Table 1). In the Channel Islands, California, elevated 
DDT levels were found in female California seal lions (Zalophus californianus) with premature parturition (Gilmartin et al. 1976). In the Dutch Wadden Sea, harbor seals with elevated concentrations of DDT and PCBs had decreased reproductive rates (Reijnders 1986). These compounds may have affected steroid hormone balance and ultimately caused immunosuppression and suppressed reproductive hormones. Uterine occlusions (a closure in uterine horns) in older female ringed seals (Phoca hispida) were associated with elevated PCB levels (Helle et al. 1976). In Puget Sound, Washington, harbor seals suffered from birth defects and a population decrease (Arndt 1973; Newby 1973). Calambokidis et al. (1984) concluded that the decline of harbor seals in Puget Sound probably was due to many factors including increased DDT and PCB levels, human disturbance, decreased prey availability, and habitat destruction. Elevated pollutant levels, combined with other factors, thereiore, may affect population success.

Few researchers have conducted manipulative experiments to determine pollutant effects on marine mammals. In one experiment, femaie harbor seals were fed daily with fish containing $1.5 \mathrm{mg}$ of PCBs (Reijnders 1986, Brouwer et al. 1989). Reijnders (1986) found reproductive success was significantly less in iemaies fed contaminated fish than those fed uncontaminated fish. He concluded that PCB disrupted hormonal pathways, thus preventing blastocyst implantation. In another experiment, Brouwer et al. (1989) concluded that PCBs decreased plasma retinol, which affected vitamin $A$ and thyroid hormone metabolism. These conditions could have resulted in immunosuppression and reproductive or pathological disorders. These are the only marine mammal 
experiments with direct indications of biological effects from elevated pollutant levels.

Trace metal accumulation also was documented in pinniped tissues, such as liver, kidney, muscle, blood, and hair (MicClurg 1984, Law et al. 1991, Wenzel et al. 1993, Yediler et al. 1993). Although many elements are essential for metabolism, they also could be toxic in excessive amounts. Metal toxicity has been documented in some terrestrial mammals, but relatively few researchers have examined metal toxicity in pinnipeds. Martin et al. (1976) speculated that premature births in California sea lions on the Channel Islands, California were attributable to several factors, including high DDE levels, leptospirosis, and trace metal imbalance. They found low concentrations of mercury, selenium, cadmium, and bromine in females and their premature pups. This trace metal deficiency may have caused an imbalance of the hepatic system, and ultimately affected their reproductive success. Hyvarinen and Sipila (1984) found elevated mercury and nickel concentrations were correlated with low selenium concentrations in stillborn ringed seals, which was associated with a population decline. In both studies, a trace element imbalance may have caused these adverse biological effects.

Because sampling live animals is difficult, most information is obtained from dead animals. Live animals, however, are the best indicator of contaminant levels in present populations (Calambokidis 1984, Reijnders 1988), and allow a better assessment of effects of contaminants on reproduction and survival of animals. Because contaminant levels vary geographically and are localized, pinnipeds with limited geographic ranges may accumulate contaminant characteristic to a particular ecosystem (Reijnders 1988). 
The Elkhorn Slough National Estuarine Research Resene (ESNERR) is located near Moss Landing, California. Hillsides that surround the slough support livestock and agriculture (mostly strawberry production). Agricultural run off is a potential source of contaminants (pesticides) into the slough. The California Department of Fish and Game (CDFG) Mussel Watch program and National Oceanic Atmospheric Administration (NOAA) monitor contaminant levels in coastal and estuarine areas along the United States. These organizations have documented large amounts of organochlorines, such as DDT, in Elkhorn Slough sediment and biota (Phillips 1988, NOAA 1989). Elkhorn Slough has the highest levels of Dacthal, Endosulfan, and Toxaphene reported in California (Phillips 1988). Pesticide levels in mussels (Mytilus californianus) from Elkhorn Slough exceed many other sites along the Pacific Coast (Table 2).

The Pacific harbor seal (Phoca vitulina richardsi) inhabits estuarine and coastal haul-out sites from Alaska to Baja, Mexico (King, 1983), including several sites in Elkhorn Slough; Channel Islands, California; Gray's Harbor, Washington; and Umpqua River, Oregon (Fig. 1). There are approximately 200 harbor seals in Elkhorn Slough, 3200 on the Channel Islands (Hanan and Beeson 1994), 760 in the Umpqua River, and 4,400 in Gray's Harbor (Brueggeman 1990). Compared with Elkhorn Slough, these other sites are relatively pristine with lesser contaminant levels (Table 2). Although harbor seals are born at all sites, relatively few pups are born in Elkhorn Slough. Four mother-pup pairs were observed in 1992, 5 in 1993, and 7 in 1994 (per. obs.). Although there are many factors that determine pupping success (e.g. site 
preference, population composition, disturbance, and hydrology), this low reproductive rate partially may be caused by elevated contaminant levels.

Harbor seals may accumulate contaminants from their ieeding area as opposed to their haul-out areas. Harbor seals, which haul-out at Grays Harbor and Umpqua River, generally feed in pristine offshore waters (S. Jeffries per. comm.). Although high contaminant levels were reported in coastal waters near the Channel Islands (Table 2), harbor seals, which haul-out on the Channel Islands, generally feed in pristine offshore waters (B. Stewart per. comm.). Although Elkhorn Slough has high contaminant levels, these high levels are not found in the surrounding waters of Monterey Bay. Harbor seals, which haul-out in Elkhorn Slough, however, fed primarily offshore in Monterey Bay and have limited feeding in Elkhorn Slough (Oxman 1995). Because of their partial feeding in Elkhorn Slough, harbor seais may have greater contaminant levels compared to harbor seals at the other sites.

The objective of this study was to determine and compare levels of synthetic organic compounds and trace elements in live harbor seals among Elkhorn Slough and the Channel Islands, California; Umpqua River, Oregon; and Gray's Harbor, Washington. I hypothesized that harbor seals from Elkhorn Slough would contain greater contaminant levels than harbor seals from the Channel Islands, Umpqua River, and Gray's Harbor. Ultimately, greater pollutant levels may cause reduced reproductive rates in harbor seals of Elkhorn Slough compared with elsewhere, although I could not test this directly.

Trace elements in the water column or sediment also can adhere to pinniped hair shafts. Although these trace elements may not be harmful, discoloration of the hair shaft may occur. Allen et al. (1993) documented 4 to 
$37 \%$ of harbor seals in San Francisco Bay had red pelage. Pelage discoloration ranged from brownish-red to orange and decreased from head to tail. During molt, red hair was shed and a new coat of normal fur slowly turned red again. Red fur appeared in both sexes of juveniles and adults. Harbor seals with red pelage were rarely observed elsewhere (Oregon, Washington, Maine, Ireland, and Japan; Allen et al. 1993).

Allen et al. (1993) attributed the red color to iron oxide accumulation on hair shafts. They postulated that iron, and other associated elements, accumulated on the hair by flocculation or precipitation. When iron recirculates in the water column during estuarine mixing, precipitates can accumulate on hair shafts. They proposed that hair was exposed to air, the iron oxidized, and fur essentially rusted. Allen et al. (1993) concluded that iron did not accumulate within hair shafts; however, they did not examine other tissues or elements. This discoloration may have been due to synergistic effects of iron with other elements. An element imbalance may be observed within the hair and other tissues. Additionally, hair structure may differ between normal and red-pelaged harbor seals. Biological effects from discoloration have not been documented.

A further objective of this study was to compare concentrations of trace elements in hair, vibrissae, liver, and muscle, between normal and red-pelaged harbor seals. To determine if red pelage was an external characteristic, trace elements were examined inside and outside hair shafts. I hypothesized that iron and other elements associated with red pelage would be detected in vibrissae, liver, and muscle samples. If trace elements were associated with discoloration, red-pelaged seals would have significantly greater trace metal concentrations in hair, vibrissae, liver, and muscle than normal-pelaged seals. I 
also hypothesized that the hair structure on red-pelaged harbor seals will appear different than normal-pelaged harbor seals. Because red hair appears primarily on the head, trace element concentrations may vary between anterior and posterior hair samples.

\section{METHODS}

\section{AMONG SITE COMPARISON}

\section{Sample Collection}

During June 1993, two harbor seals were captured in Gray's Harbor, and four harbor seals were captured in Umpqua River. From July to August 1993, nine harbor seals were captured on San Miguel and San Nicholas, Channel Islands and during October 1993, 11 harbor seals were captured in Elkhorn Slough. Harbor seals were captured in water adjacent to haul-out sites with a net deployed from a boat. Once this net was pulled ashore, seals were placed into individual nets (Jeffries et al. 1993). Only juvenile males were captured at Gray's Harbor and Umpqua River, but juvenile and adult, males and females were caught on the Channel Islands and in Elkhorn Slough (Table 3). Females were classified as juveniles if they weighed less than $32 \mathrm{~kg}$ or were less than $127 \mathrm{~cm}$ in total length, and males were classified as juveniles if they weighed less than $62 \mathrm{~kg}$ or were less than $145 \mathrm{~cm}$ (Bigg 1969).

While animals were restrained physically, blood was drawn from the extradural intervertebral venous sinus with an 18-gauge needle and plastic 
syringe. Blood was collected into Vacutainers (10 cc into a "red top" for synthetic organics and $10 \mathrm{cc}$ into a "blue top" for trace elements). Whole blood for trace element analysis was stored in biood tubes. Biood ior syninelic organic analysis was spun in a centrifuge ( $1500 \mathrm{rpms}$ for 15 minutes) to separate serum from whole blood. Serum was decanted and transferred to a high-density polyethylene container for storage.

Blubber samples only were collected from harbor seals in Gray's Harbor $(n=1)$, Umpqua River $(n=2)$, and Elkhorn Slough $(n=3)$. Each harbor seal was given $1.5 \mathrm{cc}$ of Lidocane as a local anesthetic at insertion sites. Two blubber samples were taken on either side of the mid dorsal ridge with a sterile biopsy punch and removed with forceps. Each $0.1 \mathrm{~g}$ blubber sample was stored in a high-density polyethylene container before synthetic organic analysis.

Hair samples only were collected from harbor seals in Elkhorn Slough. Hair was collected from the dorsal surface using stainless steel scissors. Hair was stored in plastic bags until trace metal analysis. Samples of blood, blubber, and hair were stored at $-20^{\circ} \mathrm{C}$ until analysis.

\section{Organochlorine Analysis}

Blood samples for synthetic organic analysis were shipped to the State Water Resource Control Board (SWRCB), CDFG in Sacramento. Samples were analyzed using standard SWRCB, CDFG methods for PCB Aroclors, DDT, metabolites, and other common pesticides (SWRCB 1994; Table 4). Each sample was dried and macerated with anhydrous granular sodium sulfate. Two 
$125-\mathrm{ml}$ portions of petroleum ether were added and samples were vacuum filtered. This extract was passed through a standard $10.16 \mathrm{~cm}$ florisil column and eluted with $250 \mathrm{ml}$ of petroleum ether, $250 \mathrm{ml}$ of $6 \%$ ether/petroleum ether, and $250 \mathrm{ml}$ of $15 \%$ ether/petroleum ether. Each fraction was concentrated to 5 $\mathrm{ml}$ and diluted to $10 \mathrm{ml}$ with isooctane. A capillary gas chromatograph (GC) equipped with an electron capture detector and autosampler was used to determine quantity of synthetic organics. For quality assurance, the GC included dual column confirmation. Six PCB and DDT standards, and blanks were analyzed for internal calibration. Additionally, field blanks were obtained by opening a blood tube at each site and handled similar to other blood tubes. Blanks and standards were analyzed using the same techniques as the samples. All samples were reported in $\mathrm{ng} / \mathrm{g}(\mathrm{ppb})$ on a fresh weight basis. All values in this study were reported to two significant figures.

For all statistical comparisons made in this study, parametric statistics were used if data sets had equal variance and data were normally distributed. Non-parametric statistics were used if data sets had unequal variance after log transformations. Organochlorine concentrations in blood were tested for equal variance with a F-test (significance level $=0.05$ ). Significant differences of means between sexes and between age classes were tested using a parametric t-test or a non-parametric Mann-Whitney $U$ test (significance level = 0.05). Significant differences among sites were tested using a 1-way ANOVA or a Kruskal-Wallis non-parametric ANOVA (significance level $=0.05$ ). Power, the probability of correctly rejecting the null hypothesis, was calculated for non significant comparisons for all data sets (Winer 1971). 
Blubber samples were shipped to the Trace Organics Laboratory at Long Marine Lab, University of California, Santa Cruz. Samples were analyzed using methods for PCB congeners, DDT metabolites, and several other compounds (Newman et al. 1994; Table 5). Briefly, the method was as follows. Each sample was extracted with anhydrous granular sodium sulfate and centrifuged with methylene chloride and hexane. Extracts was passed through a 6.35-mm gravity column filled with Florisil and separated into three fractions. Columns were eluted with $60 \mathrm{ml}$ of hexane for the first fraction. For the second and third fraction, $50 \mathrm{ml}$ of $30 \%$ methylene chloride in hexane and $70 \mathrm{ml}$ of $50 \%$ methylene chloride in hexane were added. All fractions were evaporated and topped with hexane. A GC equipped with a electron capture detector and autosampler and dual column confirmation was used to determine the quantity of synthetic organics. Chromatographs were hand checked and verified. One standard reference material (SRM) of cod liver oil and one blank were analyzed along with blubber samples. Additionally, internal standards and blanks were analyzed on a GC. Samples were reported in $\mathrm{ng} / \mathrm{g}$ on a fresh weight basis with a detection limit of $1 \mathrm{ng} / \mathrm{g}$.

Because an insufficient number of blubber samples were analyzed, statistical comparisons could not be conducted among sites. Organochlorine concentrations in blubber and blood were compared for each individual harbor seal. To compare PCB levels between blood and blubber samples, I converted blubber concentrations to Aroclor 1254, which consists of PCB congeners 52 , $99,138,153$, and 180. Aroclor 1254 was calculated by multiplying the sum of its congeners by three (Hernandez et al. 1989). To compare blood and blubber, organochlorine concentrations were tested for equal variance with a F-test 
(significance level $=0.05$ ). Significant differences of means between tissues were tested using a parametric t-test or a non-parametric Mann-Whitney $U$ test (significance level $=0.05$ ). Correlations of PCB 1254 and DDE in blood and blubber samples were tested with a Pearson's correlation for parametric analysis and a Spearman rank correlation for non-parametric analysis (significance level $=0.05$ ).

Ratios of compounds can indicate a relative chronological input of each organochlorine (Aguilar 1984). Organochlorine ratios from blubber samples were examined to determine chronological input of contaminants and potential population differences. Additionally, Aguilar (1987) stated that marine mammals populations could be distinguished by comparing DDT:DDE and total DDT (tDDT).total PCB (tPCB) ratios; therefore, ratios of DDT:DDE, Aldrin:Dieldrin, tDDT:tPCB were estimated. Total DDT (tDDT) was calculated using the sum of all DDT metabolites. Sample size was insufficient to allow for statistical comparisons. These ratios could not be calculated for blood samples, because blood only was detected for DDE and PCB 1254.

\section{Trace Element Analysis}

Trace element analytical procedures were performed according to CDFG, Mussel Watch protocols (SWRCB 1994). From each blood sample, two aliquots of $3 \pm 0.1 \mathrm{~g}$ were transferred into Teflon vessels. To determine wet-todry weight, an additional $3 \pm 0.1 \mathrm{~g}$ were placed on drying dishes in an oven at $70^{\circ} \mathrm{C}$ for 48 hours. 
Hair samples were rinsed with Milli $Q$ double distilled water (MQ) and placed in Teflon vessels. Then vessels were placed in an oven at $70^{\circ} \mathrm{C}$ for 60 hours to determine wet-to-dry weight measurements. Hair was digesied with the same procedures used for blood.

Three $\mathrm{ml}$ of 4:1 $\mathrm{HNO}_{3}: \mathrm{HClO}_{4}$ were added to each Teflon vessel, and caps were hand tightened. Teflon vessels were placed on a warm hot plate $\left(50^{\circ}-75^{\circ} \mathrm{C}\right)$ under a hood for 5 hours allowing nitric fumes to vent before placement in an oven. Because hot plates often heat unevenly, vessels were rotated on hot plates every 30 minutes. Teflon vessels were removed from hot plates and caps tightened with an automatic capper. Samples were placed in a $130^{\circ} \mathrm{C}$ oven for 4.5 hours and cooled overnight. Approximately $15 \mathrm{ml}$ of MQ was added to each sample. This solution was transferred to a tared $30-\mathrm{ml}$ polyethylene bottle and MQ was added to a total final weight of $20 \mathrm{~g}$.

Blanks and standards included three empty bombs, three field blanks (three blood tubes opened at each tagging site and later filled with $M Q$ in the lab), and SRMs of oyster tissue (Oys) or dogfish liver (Dolt). One SRM was digested for every 20 samples. For SRMs, $0.5 \pm 0.02 \mathrm{~g}$ was aliquoted into each Teflon vessel. For blood tube and syringe blanks, 3 blood tubes and syringes were filled with $20 \mathrm{ml}$ of $M Q$ and the solution was transferred to tared $30-\mathrm{ml}$ polyethylene bottles.

Samples were analyzed for cadmium (Cd), chromium (Cr), copper ( $\mathrm{Cu}$ ), lead (Pb), nickel (Ni), selenium (Se), and silver ( $\mathrm{Ag}$ ) using a Perkin-Elmer model Zeeman 3030 atomic absorption spectrophotometer equipped with an HGA 2100 graphite furnace (furnace AA). Standard additions were used to calculate Se concentrations (Beaty 1978). A Perkin-Elmer model 603 atomic 
absorption spectrophotometer with air-acetylene flame atomic absorption (flame AA) was used to analyze iron $(\mathrm{Fe})$ and zinc $(\mathrm{Zn})$. Mercury $(\mathrm{Hg})$ was analyzed with a flameless Perkin-Elmer model 603 atomic absorption spectrophotomeier (flameless AA) equipped with a flow-through cuvette using cold vapor technique (Stainton 1971). Detection limits were set by CDFG (Table 6). Element concentrations were reported in $\mu \mathrm{g} / \mathrm{g}$ (ppm) on a dry weight basis.

Trace element concentrations were tested for equal variance with a F-test (significance level $=0.05$ ). Significant differences of means between sexes and between age classes were tested using a parametric t-test or a non-parametric Mann-Whitney $U$ test (significance level $=0.05$ ). Significant differences of means among sites were tested using a 1-way ANOVA or a Kruskal-Wallis nonparametric ANOVA (significance level $=0.05$ ). Correlations among elements were tested with a Pearson's correlation for parametric analysis and a Spearman rank correlation for non-parametric analysis (significance level = 0.05).

\section{RED PELAGE COMPARISON}

\section{Sample Collection}

Five grams of liver and muscle and less than one gram of hair and vibrissae were collected from seven dead harbor seals (four adults with red pelage and three adults with normal pelage) found in San Francisco Bay from 1991 to 1993 (Table 7). Each sample was removed with stainless steel scalpels, and subsampled on a Teflon cutting board. Red (anterior) and normal 
(posterior) hair samples were collected from red-pelaged harbor seals. Hair samples were rinsed with deionized water and placed in plastic bags. Liver and muscle samples were homogenized with a titanium blade. All samples were transferred to trace metal clean jars and stored at $-20^{\circ} \mathrm{C}$.

Certain elements may adhere to external hair shafts and not be incorporated into hairs. To determine if metals only adhere to the exterior of the hair shaft, less than $1 \mathrm{~g}$ of hair was placed in $20 \mathrm{ml}$ of $\mathrm{MQ}(\mathrm{pH}=5)$ for 48 hours. Any metals adhered to external hair shafts presumably were leached into the fluid. This solution was stored at $-20^{\circ} \mathrm{C}$ until element analysis.

\section{Trace Element Analysis}

Hair and vibrissae samples were placed in Teflon vessels, and placed in an oven at $70^{\circ} \mathrm{C}$ for 60 hours to determine wet-to-dry weight measurements. All samples were digested using the same trace element techniques described previously. These samples were analyzed for $\mathrm{Cd}, \mathrm{Pb}, \mathrm{Ni}$, and $\mathrm{Se}$ on a furnace $\mathrm{AA}, \mathrm{Fe}$ and $\mathrm{Zn}$ on a flame $\mathrm{AA}$, and $\mathrm{Hg}$ on a flameless $\mathrm{AA}$. Detection limits were set by CDFG (Table 6). Element concentrations were reported in $\mu \mathrm{g} / \mathrm{g}(\mathrm{ppm})$ on a diry weight basis.

Trace element concentrations were tested for equal variance with a F-test (significance level $=0.05$ ). Significant differences between red and normalpelaged samples were tested using a parametric t-test or a non-parametric Mann-Whitney $U$ test (significance level $=0.05$ ). Correlations of elements for each tissue and correlations among tissues were tested with a Pearson's 
correlation for parametric analysis and a Spearman rank correlation for nonparametric analysis (significance level $=0.05$ ).

To examine elements coating the hair shaft, samples from two redpelaged seals and one normal-pelaged seal (Table 7) were examined with a scanning electron microscope, model SX-30 (SEM). Hairs were mounted onto SEM stubs and coated with gold using a Polaron SEM Coating System. For each sample, images were taken of hair shafts and tips. Hairs also were examined on a Jeol JSM SEM, model T330, equipped with a Princeton Gamma-Tech X-ray microanalyzer, model IMIX-XE, which quantified the composition of elements of the hair shaft. Hairs for X-ray microanalysis were mounted onto SEM stubs and carbon coated with an Anatech LTD Hummer VII coating system.

To examine hair shafts without particulate matter, hair from red and normal-pelaged harbor seals were stripped with ascorbate acid. This acid removed any metal oxides that adhered to the hair shaft. Less than $0.01 \mathrm{~g}$ of hair was soaked in $10 \mathrm{ml}$ of $30 \mathrm{mM}$ ascorbate acid $(\mathrm{pH}=2.5)$ and placed in a sonicator for an hour. Hairs were than dried and prepared for SEM analysis.

\title{
RESULTS
}

\section{AMONG SITE COMPARISON}

\author{
Organochlorine Analysis
}


For organochlorine analysis of blood, calibration and field blanks contained undetected compound levels. Only DDE and PCB 1254 were detected in blood samples from all areas. Average DDE concentration was 19 $\mathrm{ng} / \mathrm{g}$ (SE $=3.9$ ). Levels of DDE were not detected in blood samples from Gray's Harbor and Umpqua River. Fifty-six percent of samples from Channel Islands had detectable levels of DDE and $72 \%$ of samples from Elkhorn Slough had detectable levels of DDE. There was no significant difference in mean DDE concentrations between juveniles and adults at Channel Islano's $(t=1.128, p=$ $0.341, n=5)$ and Elkhorn Slough $(t=0.683, p=0.520, n=8)$. There also was no significant difference in mean DDE concentrations between Elkhorn Slough and Channel Islands $(t=2.189, p=0.051, n=13$; Fig. 2$)$. Power of both comparisons, however, was less than $10 \%$.

Average PCB concentration, among detected samples, was $200 \mathrm{ng} / \mathrm{g}$ $(S E=62)$. Levels of PCB were not detected in blood samples from Gray's Harbor. All samples from Umpqua River had detectable PCB levels, $56 \%$ from Channel Islands and 55\% from Elkhorn Slough had detectable PCB levels. Using log transformed data, there was no significant difference in PCB concentrations among Umpqua River, Channel Islands, and Elkhorn Slough ( $F$ $=1.857, p=0.198, n=15$; Fig. 3). Power of this comparison, also was less than $10 \%$.

For organochlorine analysis of blubber, calibration blanks contained undetected compound levels. Because an insufficient number of blubber samples were analyzed, statistical comparisons could not be made among Gray's Harbor, Umpqua River, and Elkhorn Slough. However, DDT and 
Dieldrin were slightly greater in Elkhorn Slough, whereas other compounds had similar concentrations among sites (Table 8).

Pesticides and PCB congeners were detected in most blubber samples (Table 9). Organochlorines concentrations could not be directly compared between blood and blubber samples. Blubber was analyzed for more compounds than blood samples. Additionally, blubber samples were analyzed for all PCB congeners, whereas blood samples only contained Aroclor 1254. Blubber concentrations of PCB congeners, which make-up Aroclor 1254, were relatively greater than other congeners (Fig. 3). Blubber had significantly greater PCB 1254 levels $(t=4.642, p=0.001, n=12$; Fig. 4) and DDE levels $(t=$ 13.912, $p=0.001, n=12 ;$ Fig. 4) than blood. There was no correlation of DDE concentrations $(r=0.003, p=0.995, n=6)$ or PCB $(r=0.192, p=0.717, n=6)$ between blood and blubber, therefore, greater organochlorine levels in blubber were not reflected in blood. For instance, harbor seal \#237ES had the highest blubber concentrations of DDE and PCB 1254; however, levels of DDE and PCB 1254 in its blood were similar to other seals (Fig. 4). Power of these correlations, however, was less than $20 \%$.

Average DDT:DDE ratio was 0.058 (SE $=0.008$ ), and average iDDT.tPCB ratio was 3.0 (SE = 0.89; Table 10). Biub́ber sámples contained greater levels of DDE than DDT and greater levels of DDT than PCB. There was no apparent difference in ratios among sites. Aldrin was not detected in any samples; however, Dieldrin was detected in all samples. Although these ratios were not calculated for blood samples, PCB 1254 was greater than DDE in all blood samples. 
Trace Element Analysis

Mean SRM trace element values for tissues were within the CDFG's certified range (Table 11). Blanks had undetectable concentrations of trace element, except for $\mathrm{Hg}$. Chromium, $\mathrm{Pb}$, and $\mathrm{Ni}$ were undetected in blood samples, whereas Cd only was detected in 9 samples ( 1 from Umpqua River, 4 from Channel Islands, and 5 from Elkhorn Slough) and Ag only was detected in 6 samples ( 1 from Channel Islands and 5 from Elkhorn Slough; Table 12). All blood samples contained detectable levels of $\mathrm{Cu}, \mathrm{Fe}, \mathrm{Se}$, and $\mathrm{Zn}$. There was no significant difference between sexes in average levels of $\mathrm{Cu}, \mathrm{Fe}, \mathrm{Se}$, and $\mathrm{Zn}$ at the Channel Islands and Elkhorn Slough (Table 12). Power of these comparisons, however, was less than $20 \%$ (Table 12). Adults had significantly greater metal values than juveniles at Elkhorn Slough for $\mathrm{Cu}(\mathrm{t}=2.876, n=10)$, Fe $(t=2.508, n=10)$, Se $(t=2.303, n=10)$, and $Z n(t=2.886, n=10 ;$ Fig. 5$)$. Because juveniles were significantly less than adults, only juveniles were used to compare concentrations among samples from Gray's Harbor, Umpqua River, Elkhorn Slough, and the Channel Islands. There were no significant differences among sites for $\mathrm{Cu}(F=0.112, n=17)$, Se $(F=0.223, n=17)$, $\mathrm{Zn}$ (using log transiormed daia; $F=0.060, n=17$ ), and $F e$ (using a Kruskal Wallis; $H=2.353, n=17$ ) concentrations (Fig. 6). Power of these comparisons; however, was less than $10 \%$ (Table 12).

Combining blood samples from all sites $(\mathrm{n}=23), \mathrm{Cu}, \mathrm{Fe}, \mathrm{Se}$, and $\mathrm{Zn}$ were significantly correlated. Using a Pearson's pairwise comparison, correlation were as follows: Se and $\mathrm{Cu}: \mathrm{r}=0.685, \mathrm{p}<0.01, \mathrm{Fe}$ and $\mathrm{Cu}: \mathrm{r}=$ 
$0.754, p<0.01$; Fe and Se: $r=0.784, p<0.01$; Fe and $Z n: r=0.881, p<0.01$;

Se and $\mathrm{Zn:} r=0.546, p=, 0.042 ; \mathrm{Zn}$ and $\mathrm{Cu}: r=0.605, p=0.013)$.

Samples and SRMs were contaminated with $\mathrm{Hg}$ during digestion procedures. Digestion blanks also were contaminated $(\bar{\chi}=45 \mu \mathrm{g} / \mathrm{g})$; however, field, syringe, and blood tube blanks were not contaminated. Subtracting digestion blariks, average $\mathrm{Hg}$ levels were similar among sites: Gray's Harbor $\bar{\chi}=0.44 \mu \mathrm{g} / \mathrm{g}(\mathrm{SE}=0.16)$, Umpqua River $\bar{\chi}=0.96 \mu \mathrm{g} / \mathrm{g}(\mathrm{SE}=0.7)$, Channel Islands $\bar{\chi}=0.48 \mu \mathrm{g} / \mathrm{g}(\mathrm{SE}=0.26)$, and Elkhorn Slough $\bar{\chi}=0.59 \mu \mathrm{g} / \mathrm{g}$ (SE $=$ 0.16). Furthermore, $\mathrm{Hg}$ levels also were similar among sexes and age classes.

Because many of the digestions were $\mathrm{Hg}$ contaminated, an additional five blood samples from Elkhorn Slough were analyzed to test digestion procedures for contamination. It was suspected that cross contamination of samples occurred during digestion procedures. Using extreme caution to avoid contamination, Teflon vessels were heated on separate hot plates and a separate pipette was used to aliquot MQ into each sample. Additionally, vessels were hand tightened before placing them onto heating plates (previously they were loosely tightened). In this digestion, there was no $\mathrm{Hg}$ contamination of blanks or SRMs. Average $\mathrm{Hg}$ concentration for these samples was 0.76 (SE $=0.22$ ), which was similar to contaminated blood samples.

All analyzed elements were detected in hair samples from Elkhorn Slough (Table 12). There was no significant difference in concentration of elements tested between genders or ages of harbor seals of Elkhorn Slough. Power of the tests for sex comparisons was less than $20 \%$ (Table 12). Power of age comparisons was less than 15\%, except for Ag, which was $99 \%$ (Table 12). 
For hair samples from Elkhorn Slough, $\mathrm{Hg}$ was not detected in field blanks; however, concentrations of digestion blanks were high $(\bar{\chi}=59 \mu \mathrm{g} / \mathrm{g})$. Average levels were similar between males $(35 \mu \mathrm{g} / \mathrm{g}, \mathrm{SE}=5.3)$ and femaies ( 34 $\mu \mathrm{g} / \mathrm{g}, \mathrm{SE}=10 \mu \mathrm{g} / \mathrm{g}$. Average levels also were similar between adults $(39 \mu \mathrm{g} / \mathrm{g}$, $\mathrm{SE}=6.5)$ and juveniles $(30 \mu \mathrm{g} / \mathrm{g}, \mathrm{SE}=5.4)$.

Hair samples had elevated $\mathrm{Zn}$ concentrations $(\bar{\chi}=120 \mu \mathrm{g} / \mathrm{g}, \mathrm{SE}=290)$. To test for external $\mathrm{Zn}$ contamination and cleaning procedures, l obtained hair samples from four males and one female juvenile harbor seals from Puget Sound and Washington coast. First, $0.1 \mathrm{~g}$ of hair was rinsed with $M Q$ and digested (same method used on other hair samples). Another $0.1 \mathrm{~g}$ of hair was cleaned by soaking it in $1.5 \% \mathrm{HNO}_{3}$ for 4 hours. I cleaned an additional $0.1 \mathrm{~g}$ of hair by soaking it in $1.5 \% \mathrm{HNO}_{3}$ for 24 hours. Average $\mathrm{Zn}$ concentration was $290 \mu \mathrm{g} / \mathrm{g}(\mathrm{SE}=68$ ) when rinsed with MQ, $28 \mu \mathrm{g} / \mathrm{g}$ (SE = 5.4) for samples soaked in $M Q$ for 4 hours, and $26 \mu \mathrm{g} / \mathrm{g}$ (SE $=4.6$ ) for samples soaked in $M Q$ for 24 hours. Because uncleaned samples had greater $\mathrm{Zn}$ concentrations than cleaned samples $(p=0.020)$, significant amounts of $Z n$ were removed from the external surface of hair during this cleaning process. I did not test for external contamination of hair samples of other elements, because their concentrations were not as great as $\mathrm{Zn}$.

Only $\mathrm{Ni}$ and $\mathrm{Cu}$ in hair were positively correlated (using log transformed data, $r=0.617, n=11$ ). More elements were detected in hair samples than blood samples from Elkhorn Slough. Concentrations of $\mathrm{Cu}$ and $\mathrm{Zn}$ were significantly greater in hair than in blood, whereas $\mathrm{Fe}$ and $\mathrm{Se}$ were similar in hair and blood (Fig. 7). Concentrations of elements were not correlated between blood and hair values for individual harbor seals. 


\section{RED PELAGE COMPARISON}

There were few differences among element concentrations in tissues of red and normal-pelaged harbor seals. Lead was not detected in muscle samples. In liver samples, $\mathrm{Pb}$ was detected in all red-pelaged harbor seals $\sqrt{\bar{x}}=$ $0.73 \mu \mathrm{g} / \mathrm{g}, \mathrm{SE}=0.14)$, and only in one normal-pelaged seal $(\bar{\chi}=0.20 \mu \mathrm{g} / \mathrm{g})$. Because of insufficient sample size, however, $\mathrm{Pb}$ was dropped from the analysis. Concentrations of $\mathrm{Cd}, \mathrm{Fe}, \mathrm{Hg}, \mathrm{Ni}, \mathrm{Se}$, and $\mathrm{Zn}$ were detected in all liver and muscle samples (Table 13). Significantly less Ni was in the liver of redpelaged harbor seals than harbor seals with normal pelage $(t=2.970, n=7)$. There was no significant difference in other elements in liver and muscle of red and normal-pelaged harbor seals. Power, however, was less than $10 \%$ for most of these comparisons (Table 13).

Liver and muscle samples also were contaminated with $\mathrm{Hg}$. Although $\mathrm{Hg}$ concentration in empty digestion vessels were elevated $(\bar{\chi}=130 \mu \mathrm{g} / \mathrm{g})$, average $\mathrm{Hg}$ concentrations in the liver were similar between red and normalpelaged harbor seals (red: $\bar{\chi}=210 \mu \mathrm{g} / \mathrm{g}, \mathrm{SE}=19$ and normal: $\bar{\chi}=170 \mu \mathrm{g} / \mathrm{g}$, $\mathrm{SE}=69$ ) and muscle (red: $\bar{\chi}=6.7 \mu \mathrm{g} / \mathrm{g}, \mathrm{SE}=4.4$ and norma! $\bar{\chi}=8.7 \mu \mathrm{g} / \mathrm{g}, \mathrm{SE}$ $=1.7$ ).

All elements were detected in hair samples (Table 13). There was no significant difference in metal concentrations between anterior and posterior hair samples from red-pelaged harbor seals (Table 14). Therefore, average concentrations of elements (anterior and posterior samples) from red-pelaged harbor seals were compared with normal-pelaged harbor seals. There was no 
significant difference in metal concentrations between red and normal-pelaged hair samples (Table 13). Power for $\mathrm{Fe}, \mathrm{Hg}$, and $\mathrm{Zn}$ comparisons was $99 \%$, and below $70 \%$ for other elements (Table 13). Overall, red and normai-peiaged harbor seals had similar levels of $\mathrm{Fe}$ in their tissues.

Trace elements were analyzed in vibrissae from two normal-pelaged and one red-pelaged harbor seal. Because of insufficient sample size, vibrissae samples were not compared statistically . Levels of $\mathrm{Cd}, \mathrm{Fe}, \mathrm{Pb}, \mathrm{Hg}, \mathrm{Ni}$, $\mathrm{Se}$, and $\mathrm{Zn}$ were less in vibrissae samples than other hair samples (Table 13). There were no trends in element concentrations in vibrissae of red versus normal-pelaged harbor seals.

Only Fe and Zn were leached from some hair samples soaked in MQ. Among detected samples, $\mathrm{Fe}(\bar{\chi}=0.93 \mu \mathrm{g} / \mathrm{g}, \mathrm{SE}=0.15)$ and $\mathrm{Zn}(\bar{\chi}=0.17 \mu \mathrm{g} / \mathrm{g}$, $S E=0.03$ ) were similar among all hair samples. Because of insufficient data, no statistical comparisons were conducted. These low concentrations may represent external contamination because of insufficient cleaning.

Few elements in tissues were correlated between red and normalpelaged harbor seals. Correlations were not consistent among tissue samples. For instance, $\mathrm{Pb}$ and $\mathrm{Cd}$ were correlated in liver samples from red-pelaged harbor seals $(r=0.965, p=0.035, n=4)$ but not in their hair samples (Table 15). Lead and $\mathrm{Ni}(r=0.958, \mathrm{p}=0.042, \mathrm{n}=4)$ and $\mathrm{Hg}$ and $\mathrm{Se}(r=0.972, \mathrm{p}=0.028, \mathrm{n}$ $=4$ ) were correlated significantly in red hair samples, whereas no element values correlated in normal hair samples. Additionally, $\mathrm{Cd}$ and Se were the only elements that correlated in liver samples from normal-pelage seals $(r=$ $0.999, p=0.026, n=3$ ). Because of insufficient sample size, many samples were not analyzed. Lead was detected in only one normal-pelaged liver 
sample, and Se was detected in only two normal-pelaged hair samples. These elements, therefore, were not used in normal-pelage comparisons. No element values correlated within vibrissae or muscle samples.

Hair from normal-pelaged harbor seals had minimal particulate accumulation and symmetrical cuticle scaling, as scanned with a SEM (Fig. 8). Particulate matter coated most of the anterior and posterior hairs of red-pelaged harbor seals (Fig. 9). This coating was clumped or layered and the hair had no cuticle. Normal and red-pelaged hairs stripped in ascorbate acid had no deposits and scaling was either absent or irregular (Figs. 10-11). This acid had stripped all deposits and both pelages appeared similar.

Hairs were scanned with a SEM X-ray, in selected areas, and an element histogram was calculated. Because hair is composed of cystine proteins, which are sulfur based, hair samples contained mostly sulfur. Red and normalpelaged hair samples contained varying amounts of aluminum, calcium, chlorine, iron, magnesium, phosphorous, potassium, silicon, and sulfur. There were no consistent trends in amounts of elements for each sample (Table 15). Amounts of $\mathrm{Fe}$ were similar on red and normal hairs. Stripped hair samples were composed mostly of sulfur (>90\%) and only trace amounts of other elements.

\section{DISCUSSION}

Marine mammal researchers often have limited number of samples, because it is difficult and expensive to obtain a large sample size. Additionally, sample composition often cannot be controlled. In this study, few harbor seals 
were sampled at each site, and age and sex of these harbor seals was not consistent. Additionally, samples were collected during different seasons. Age, sex, and location of seals can influence contaminant levels, and if not controlled by sample design, variability among samples can be great. Because of great variance among samples, comparisons often had power less than $10 \%$. To increase power, most comparisons would require greater than 100 samples. For instance, to obtain $80 \%$ power, 610 samples would be needed for comparisons of PCB concentrations and 780 samples would be needed for $\mathrm{Cu}$ concentrations. This sample size was calculated by setting a desired effect size of the least difference among mean concentrations. Required sample size actually may be less than the calculated sample size, because as sample size increases, effect size may decrease. Additionally, correlations were calculated with few samples; therefore, significant correlations may be due to chance. Although an increased sample size would likely decrease variability, analysis and collection were restricted by cost and difficulty of obtaining samples. Because bioaccumulation studies may have a limited sample size, these conclusions are tentative.

\section{AAMONG SITE COMPARISON}

Organochlorine Analysis

Blood values for PCB 1254 and DDE were similar to levels previously reported from San Francisco (Kopec and Harvey 1995, Table 16), although Kopec and Harvey (1995) and this study reported great variability. Several 
organochlorine concentrations in blubber were less than levels reported in previous studies (Table 16).

Elevated contaminant levels in harbor seals could be a reflection on ambient marine levels. Because DDT was used near Elkhorn Slough historically and produced near Los Angeles, greater DDT levels were expected in harbor seals of Elkhorn Slough and Channel Islands from potential run-off. Although there was no statistical difference of contaminant levels among sites, Elkhorn Slough had slightly greater levels than other sites. These blood and blubber samples, however, had lesser contaminant concentrations than anticipated. Historically, Elkhorn Slough and Channel Islands may have high contaminant; however, these contaminants may slowly break down through time. California sea lions on the Channel Islands had a significant decrease in DDT levels during the past 20 years (Leiberg et al. 1995). Perhaps contaminants in these harbor seal feeding areas have also decreased through time.

These relatively low contaminant levels may be a reflection of the food habits of harbor seals foraging near San Miguel and San Nicholas, Channel Islands, far from Los Angles (B. Stewart per. comm.). Harbor seals in Elkhorn Slough ied primariiy orishore (Oxman 1995). Contaminant levels aro lower off shore than in Elkhorn Slough (Phillips 1988); therefore, harbor seal prey probably have low contaminant levels. Low organochlorine concentrations may confirm that harbor seals in Elkhorn Slough forage mostly offshore in Monterey Bay.

Organochlorine concentrations were greater in blubber samples than in blood samples, because these compounds are lipophilic and concentrate in 
fatty tissues. Organochlorines may become mobilized into the blood stream during stress or starvation (Aguilar 1987, Reijnders 1988). Harbor seals that suffered from stress and star/ation in the North Sea had greater organochiorine levels than harbor seals in this study (Reijnders 1988). Because organochlorines in blubber and blood were less than previous studies, harbor seal populations at Gray's Harbor, Umpqua River, Elkhorn Slough, and Channel islands may not be stressed by contaminants.

Because blood and blubber were analyzed with different techniques, organochlorine results cannot be compared directly with other studies. Blood was analyzed for PCB 1254 and blubber was analyzed for PCB congeners. Although PCB 1245 was estimated for blubber samples, these results are approximations. Concentrations of DDE were analyzed in blood and blubber, which may be a better comparison of concentrations in these two tissues. Techniques used for analyzing blubber detected more compounds than those used for blood; however, blubber analysis is more expensive and labor intensive. Organochlorines in blood may represent present contaminant levels, whereas organochlorines in blubber may represent stored levels.

Concentrations of contaminants were not correlated in blood and blubber; therefore, analyzing both yielded different trends. Analyzing blood and blubber are important for bioaccumulation studies. Blood analysis would be preferred for baseline studies with a large amount of samples to evaluate present contaminant levels, whereas blubber analysis would be preferred for identitying specific compounds and their long-term accumulation.

Examining compound ratios can indicate a relative chronological input of each organochlorine (Aguilar 1984). For example, (tDDT) degrades into DDE. 
If the $\mathrm{LDDT}: D D E$ ratio was large, then DDT recently was introduced into an environment. Blubber samples from Gray's Harbor, Umpqua River, and Elkhorn Slough contained primarily DDE, indicating that DDT input was not recent. Similarly, Aldrin degrades into Dieldrin. Because some samples only contained Dieldrin, Aldrin input was not recent. Concentration of DDE and Dieldrin were slightly greater in Elkhorn Slough than other sites, similar to those observed in shellfish from these sites (DDE>DDT and Dieldrin>Aldrin; Phillips 1988). Dieldrin and DDT once were used in agricultural practices around Elkhorn Slough. These pesticides have not been used in the past 20 years, and are slowly degrading in the sediment (Phillips 1988). Aguilar (1987) stated that marine mammals populations could be distinguished by comparing DDT:DDE and tDDT:TPCB ratios. In this study, however, ratios were similar among sites (i.e., DDT < DDE and tDDT < $\mathrm{TPCB}$ ). A difference in compound ratios may be detected with a larger samples size.

\section{Trace Element Analysis}

Most element concentrations in blood were similar to levels reported in previous siudies; however, element concentrations in hair samples were greater than levels reported in previous studies (Table 17). In previous studies, researchers have detected differences among sites (Reijnders 1980, Calambokidis et al. 1984, Aguilar 1987). Differences among site are usually detected in adults, which have accumulated pollutants during a longer period of time. Perhaps, in this study, differences could be observed in adults from these different populations, rather than juveniles, which mostly had undetected levels. 
For this reason, it is important to sample adults and juveniles. Several researchers have documented differences in contaminant levels, including males with greater levels than females and adults with greater levels than juveniles (Helle et al. 1976, Martin et al. 1976, Reijnders 1980, Calambokidis et al. 1984, Hyvarinen and Sipila 1984, Aguilar 1987, Subramanian et al. 1987, Reijnders 1988). Although no significant difference was observed between sexes in this study, it may have been due to the small sample size.

Because blood constantly flows ihrough an animal, concentrations of pollutants in blood represent current levels, not levels accumulated through time. Elements can be stored in tissues such as hair. Metals that adhere to external hair shafts could cause a bias, because external contamination could raise sample concentrations. Metals remained on hair shafts after they were rinsed with $M Q$, whereas acid cleaned hair samples had a significant amount of $\mathrm{Zn}$ removed. Bencko (1991) suggested a standardized cleaning method by rinsing hair first in a nonpolar solvent, then in a polar solvent, and finally in acetone. Hinners et al. (1974) suggested that external concentrations also should be measured because they may represent environmental contaminants. Researchers, therefore, should examine internal and external elements during contaminant analysis of hair. Additionally, hair samples had elevated $\mathrm{Zn}$ concentrations, possibly because they were contaminated or were not properly cleaned, and sediment adhered to the hairs. Because a small amount of tissue was used (less than $1 \mathrm{~g}$ ), dilution factors were high (50-300). High dilution factors may introduce variability, because concentration was determined from a small amount of sample. In monitoring studies, hair and blood samples should be collected, because both tissues offer valuable information on pollutants. 
Hair samples were easy to obtain and indicated long-term exposure to pollutants, whereas blood was more difficult to collect but indicated presence of trace elements in a system (Bencko 1991, Subramanian 1991).

Often a correlation or an imbalance of elements can cause physiological effects. Some of the correlations observed in this study were previously documented with physiological effects in other species (Friberg et al. 1979, Piscator 1979, Tsuchiya 1979). Because $\mathrm{Cu}$ and Fe are used to form hemoglobin, l expected these two elements would be positively correlated with each other (Piscator 1979). An imbalance of $\mathrm{Cu}$ and $\mathrm{Zn}$ caused cardio-vascular or gastrointestinal diseases in humans (Piscator 1979). These diseases should not have affected these seal populations, because $\mathrm{Cu}$ and $\mathrm{Zn}$ were significantly correlated and levels were similar to other pinniped populations. In humans, Fe deficiency has caused an increase in Pb concentrations (Tsuchiya 1979). in this study, blood had elevated Fe concentrations and was significantly correlated with $\mathrm{Pb}$. Therefore, these harbor seals should not suffer from $\mathrm{Fe}$ deficiency.

Although most samples were contaminated with $\mathrm{Hg}$, levels were similar to concentrations previously reported (Calambokidis et al. 1984, Wagemann et al. 1988, Wenzel et al. 1993, Kopec and Harvey 1995). Contamination probably occurred during the digestion process. Vapors containing $\mathrm{Hg}$ may have contaminated other samples when lids were opened under a ventilation hood. To prevent contamination, samples should be handled individually. Most contaminant values were less than previous studies, in which adverse pollutant effects were observed. Levels reported in this study; therefore, should not cause a decrease in reproductive rates. Low reproductive 
rates in Elkhorn Slough probably are not caused by elevated contaminants; rather they may be attributed to site preference, population composition, disturbance, or hydrology. The number of harbor seals in Elkhorn Slough has grown dramatically in the past 15 years, from 20 harbor seals in 1982 to 200 in 1993 (Hanan and Beeson 1994). Perhaps as the population continues to grow, more harbor seals will reproduce in Elkhorn Slough. Because areas in Elkhorn Slough are recently established haul-out sites, it may take several years to become a preferred pupping site. Harbor seals will segregate during breeding seasons with females using preferred pupping sites (Thompson 1989, Kovacs et al. 1990). Perhaps most sexually mature females leave Elkhorn Slough during the breeding season and move to established pupping sites along the coast. Elkhorn Slough is a shallow winding waterway. All harbor seal haul-out sites face the main channel and are subject to moderate disturbance írom boat traffic. Harbor seals may prefer pupping along open coasts, which hay a easy escape from disturbance (Allen et al. 1984). Often pupping sites are protected, where people have restricted access (Harvey et al. 1990). Pupping sites are determined by several factors such as population composition, location, and disturbance. Many of these factors may affect pupping in Elkhorn Slough.

\section{RED PELAGE COMPARISON}

Allen et al. (1993) attributed red pelage to Fe oxidizing on hair shafts. In this study, however, red-pelaged harbor seals did not have significantly greater amounts of $\mathrm{Fe}$ on their fur or in any other tissues than harbor seals with normal pelage. Furthermore, significant Fe concentrations were not detected in hair 
soaked in acid or with SEM X-ray analysis, suggesting that red pelage was not caused by greater Fe concentrations. There may be, however, another factor that allowed a combination of elements to oxidize on hair shafts.

Hair is comprised mainly of keratin, a sulfur-based protein called cystine. Each hair has several layers. The outer layer has a scaly appearance formed from flattened cuticle cells. The epicuticle is a thin coating that covers these layers and is resistant to oxidation and other element reactions, whereas the cuticle is highly reactive (Fraser et al. 1972). Hair from red-pelaged harbor seals may lack an epicuticle layer, allowing $\mathrm{Fe}$ and other elements to react with the hair. As viewed using an SEM, hairs from red-pelaged harbor seals had irregular scaling, and were coated with clumped particulate matter. It is possible that an absent or irregular epicuticle layer provided a surface for adherence of elements normally associated with hair.

It is possible, certain elements or compounds react with hair, removing the epicuticle. Compared with other studies, tissue samples had greater concentrations of most elements (Tables 17 - 18), and Ni was in greater concentration in liver of red-pelaged seals than normal-pelaged harbor seals. Reduced Ni concentrations may affect hair shafts. In humans, Ni toxicity can cause dermatitis, which is an irritation and sloughing of skin (Norseth and Piscator 1979). Possibly the Ni imbalance in red-pelaged harbor seals may have caused sloughing of the epicuticle layer allowing, Fe to react with the cuticle layer. Correlations; however, were not consistent among tissue sampies. There may be an interaction between elements; however, a larger samples size would be needed to confirm these correlations. 
Although red-pelaged seals did not have significant amount of Fe on their fur, it appears that their hair is coated with particulate matter. If the red color is indeed caused by $\mathrm{Fe}$ accumulation, it may be another element that causes a reaction with hairs, and not necessarily increased Fe concentrations. There is a need for investigation of the interaction of elements on hair samples and physical properties of red hairs (i.e., cuticle scaling or porosity). Most importantly, a larger sample size is required.

In this study, no direct pollutant effects were measured. Without controlled experiments, it may be difficult to conclude direct effects of pollutants. Such effects may result from a combination of environmental factors.

Contaminants may affect organisms with synergistic or antagonist reactions with other chemicals. Limited food source or disease also may compound pollutant effects. Researchers studying bioaccumulation also need to monitor other environmental factors that may contribute to pollutant effects. 
LITERATURE CITED

Aguilar, A. 1984. Relationship of DDE/tDDT in marine mammals to the chronology oi DDT input inte the ecosystem. Can. I. Fish. Aquat. Sci. 41:840-844.

Aguilar, A. 1987. Using organochlorine pollutants to discriminate marine mammal populations: A review and critique of the methods. Mar. Mam. Sci. 3(3):242-269.

Allen, S., D. Ainley, G. Page, C. Ribic. 1984. The effect of disturbance on harbor seal haul out patterns at Bolinas Lagoon, California. Fish. Bull. 82(3):493-500.

Allen, S., M. Stephenson, R. Risebrough, L. Fancher, A. Shiller, D. Smith. 1993. Red-pelage harbor seals of the San Francisco Bay region. J. Mam. 74(3):588-593.

Arndt, D. 1973. DDT and PCB levels in three Washington state harbor seal (Phoca vitulina richardsii) populations. MS Thesis, Univ. Washington, Seattle, WA. 65p.

Beaty, R. 1978. Concepts, Instrumentation and Techniques in Atomic Adsorption Spectrophotometry. Perkin-Elmer Corp.

Bencko, V. 1991. Biological monitoring of environmental pollution and resulting human exposure to trace metal by hair analysis. in Biological Monitoring of Exposure to Chemicals: Metals. H. Dillon, M. Ho (ed.). John Wiley and Sons. NY, NY, USA. 255-261.

Bigg, M. 1969. The harbor seal in British Columbia. Fish. Res. Bd. Can. Bull. 171:1-33.

Britt, J., E. Howard. 1983. Tissue residues of selected environmenis in marine mammals. in Pathobiology of Marine Mammal Diseases. vol. 2. E. Howard ed. CRC Press. p80-94.

Brouwer, A., P. Reijnders, J. Koeman. 1989. Polychlorinated biphenyl (PCB) contaminated fish induces vitamin $A$ and thyroid hormone deficiency in the common seal (Phoca vitulina). Aquat. Tox. 15:99-106.

Brueggeman, J. (ed.). 1990. Oregon and Washington Marine Mammal and Seabird Surveys: Information Synthesis and Hypothesis Formulation. Portland, OR, USA. 374p. 
Buchman, M. 1989. A Review and Summary of Trace Contaminant Data for Coastal and Estuarine Oregon. NOAA Tech Mem. NOS OMA 42. 115p.

Calambokidis, J., J. Peard, G. Steiger, J. Cubbage, R. DeLong. 1984.

Chemical contaminants in marine mammals from Washington state. NOAA Technical Memorandum. 167p.

DeLong, R., W. Gilmartin, J. Simpson. 1973. Premature births in California sea lions: association with high organochlorine pollutant residue levels. Science 181:1168-1170.

Fraser, R., T. MacRae, G. Rogers. 1972. Keratins Their Composition, Structure and Biosynthesis. Charles Thomas Publisher. Springfield, IL, USA. $304 p$.

Freeman, H., J. Uthe, G. Sangalang. 1980. The use of steroid hormone metabolism studies in assessing the sublethal effects of marine pollution. Rapp P. v. Reun. Cons. int. Explor. Mer, 179:16-22.

Friberg, L., T. Kjellström, G. Nordberg, M. Piscator. 1979. Cadmium. in Handbook on the Toxicity of Metals. L. Friberg, G. Nordberg, V. Vouk (eds.). Elsevier/North-Holland Biomedical Press. NY, NY, USA. 355381.

Gaskin, D., R. Frank, M. Holdrinet, K. Ishida, C. Walton, M. Smith. 1973. Mercury, DDT, and PCB in harbour seal (Phoca vitulina) from the Bay of Fundy and Gulf of Maine. J. Fish. Res. Board Can. 30:471-475.

Gilmartin, W., R. DeLong, A. Smith, J. Sweeney, F. DeLappe, B. Risebrough, L. Griner, M. Dailey, D. Peakall. 1976. Premature parturition in California sea lion. J. Wildlife Dis. 12:104-115.

Hanan, D., M. Beeson. 1994. Harbor seal, Phoca vitulina richardsi, census in California, May-June, 1993. NOAA Fisheries/NMFS, Southwest Fisheries Science Center. 61p.

Harvey, J., R. Brown, B. Mate. 1990. Abundance and distribution of harbor seais (Phoca vitulina) in Oregon, 1975-1983. Nothwestern Naturalist $71: 65-71$.

Helle, E. 1976. PCB levels correlated with pathological changes in seal uteri. Ambio 5(5-6):261-263.

Helle, E., M. Olsson, S. Jensen. 1976. DDT and PCB levels and reproduction in ringed seal from the Bothnian Bay. Ambio 4:188-189. 
Hernandez, L., M. Fernandez, M. Gonzalez. 1989. Total PCBs and PCB congeners in Spanish Imperial Eagle eggs. Bull. Environ. Contam. Toxicol. 43(5):725-732.

Hinners, T., W. Terrill, J. Kent, A. Colucci. 1974. Hair-metal binding. Environ. Health Perspectives 8:191-199.

Hyvarinen, H., T. Sipila. 1984. Heavy metals and high pup mortality in the Samiaa ringed seal population in eastern Finland. Mar. Poll. Bull. 15(9):335-337.

Jeffries, S., R. Brown, J. Harvey. 1993. Techniques for capturing, handling and marking harbour seals. Aquatic Mam. 19(1):21-25

King, J. 1983. Seals of the World. National History Museum Publications Ithica, NY, USA.

Kopec, D., J. Harvey. 1995. Toxic pollutants, health indices, and population dynamics of harbor seals in San Francisco Bay, 1989-1992. Moss Landing Marine Laboratories unpubl. report.

Kovacs, K., K. Jonas, S. Welke. 1990. Sex and age segregation by Phoca vitulina concolor at haul-out sites during the breeding season in the Passamaquoddy Bay region, New Brunswick. Mar. Mam. Sci. 6(3):204214.

Law, R., C. Fileman, A. Hopkins, J. Baker, D. Jackson, S. Kennedy, A. Martin, R. Morris. 1991. Concentrations of trace metals in the livers of marine mammals (seals, porpoises and dolphins) from waters around British Isles. Mar. Poll. Bull. 22(4)183-191.

Leiberg-Clark, P., C. Bacon, S. Burns, W. Jarman, B. LeBoeuf. 1995. DDT in California sea-lions: a follow-up study after twenty years. Mar. Poll. Bull. $30(11) 744-745$.

Martin, J., P. Elliott, V. Anderlini, D. Grivin, S. Jacobs, R. Risebrough, R. DeLong, W. Gilmartin. 1976. Mercury-selenium-bromine imbalance in premature parturient California sea lions. Mar. Bio. 35:91-104.

McClurg, T. 1984. Trace metals and chlorinated hydrocarbons in Ross seals from Antarctica. Mar. Poll. Bull. 15(10):384-389.

Michaels, A., A. Flegal. 1990. Lead in marine plaktonic organisms and pelagic food webs. Limnol. Oceanogr. 35(2):287-295.

Newby, T. 1973. Changes in the Washington state harbor seal population. Murrelet 75p. 
Newman, J., J. Vedder, W. Jarman, R. Chang. 1994. A methods for the determination of environmental contaminants in living marine mammals using microscale samples of blubber and blood. Chemosphere 28(10):1795-1805.

NOAA Technical Report, 1989. A summary of data on tissue contamination from the first three years (1986-1988) of the mussel watch project. NOS OMA 49. Rockville, MD. 148p.

Norseth, T., M. Piscator. 1979. Nickel. in Handbook on the Toxicity of Metals. L. Friberg, G. Nordberg, V. Vouk (eds.). Elsevier/North-Holland Biomedical Press. NY, NY, USA. 541-553.

Oxman, D. 1995. Seasonal abundance, movements, and food habits of harbor seals (Phoca vitulina richardsi) in Elkhorn Slough, California. MS Thesis California State University Stanislaus.

Piscator, M. 1979. Copper. in Handbook on the Toxicity of Metals. L. Friberg, G. Nordberg, V. Vouk (eds.). Elsevier/North-Holland Biomedical Press. NY, NY, USA. 411-419.

Phillips, D. 1980. The effects of lipid on the accumulation of organochlorines and trace metals by biota. in: Quantitative Aquatic Biological Indicators: Their us to monitor trace metal and organochlorine pollution. Applied Sciences Publ. Ltd. London. 38-181p.

Phillips, P. 1988. California state Mussel Watch ten year data summary 19771987. Water Quality Monitoring Report No. 87-3. 315p.

Reijnders, P. 1980. Organochlorine and heavy metal residues in harbour seals from the Wadden Sea and their possible effects on reproduction. Neth. J. Sea Res. 14(1):30-65.

Reijnders, P. 1986. Reproductive failure in common seals feeding on fish from polluted coastal waters. Nature 324(4):456-457.

Reijnders, P. 1988. Ecotoxicological perspectives in marine mammology: research principles and goals for a conservation policy. Mar. Mam. Sci. 4(2):91-102.

Risebrough, R. 1978. Pollutants in marine mammals, a literature review and recommendations for research. Mar. Mam. Com. 64p.

Shaw, G., D. Connell. 1982. Factors influencing concentrations of polychlorinated biphenyls in organisms from an estuarine ecosystem. Aust. J. Mar. Freshw. Res. 33:1057-1070. 
Stainton, M. 1971. Syringe procedure for transfer of nanogram quantities of mercury vapor for flameless atomic absorption spectrophotometry. Anal. Chem. 43(4):625-627.

State Water Resources Control Board. 1994. State of California Department of Fish and Game Environmental Services Division Laboratory Quality Assurance Program Plan. Interagency Report.

Subramanian, A., S. Tanabe, R. Tatsudawa, S. Siato, N. Miyazaki. 1987. Reduction in the testosterone levels by PCBs and DDE in Dall's porpoises and the northwestern North Pacific. Mar. Poll. Bull. 18(12):643-646.

Subramanian, R. 1991. Metals in hair as an indicator for metal burden of the body. in Biological Monitoring of Exposure to Chemicals: Metals. iri. Dillon, M. Ho (ed.). John Wiley and Sons. NY, NY, USA. 255-261.

Szefer, P., K. Szefer, E. Holm 1994. Distribution and coassociations of selected metals in seals of the Antarctic. Environ. Poll. 83:341-349.

Thompson, P. 1989. Seasonal changes in the distribution and composition of common seal (Phoca vitulina) haul-out groups. J. Zool., Lond. 217:281294.

Tsuchiya, K. 1979. Lead. in Handbook on the Toxicity of Metals. L. Friberg, G. Nordberg, V. Vouk (eds.). Elsevier/North-Holland Biomedical Press. NY, NY, USA. 451-484.

Wagemann, R., R. Stewart, W. Lockhart, B. Stewart, M. Povoledo. 1988. Trace metals and methyl mercury: associations and transfer in harp seals (Phoca groenlandica) mothers and their pups. Mar. Mam. Sci. 4(4):339355.

Wagemann, R. 1989. Comparison of heavy metals in two groups of ringed seals (Phoca hispida) from the Canadian Arctic. Can. J. Fish. Aquat. Sci. 46:1558-1563.

Wenzel, C., D. Adelung, H. Kruse, O. Wassermann. 1993. Trace metal accumulation in hair and skin of the harbour seal, (Phoca vitulina). Mar. Poll. Bull. 26(3):152-155.

Winer, B. 1971. Statistical Principles in Experimental Design. 2nd ed. McGrawHill, Inc. NY, NY, USA. 908p.

Yediler, A., A. Panou, P. Schramel. 1993. Heavy metals in hair samples of the Mediterranean Monk Seal (Monachus monachus). Mar. Poll. Bull. 26(3):156-159. 


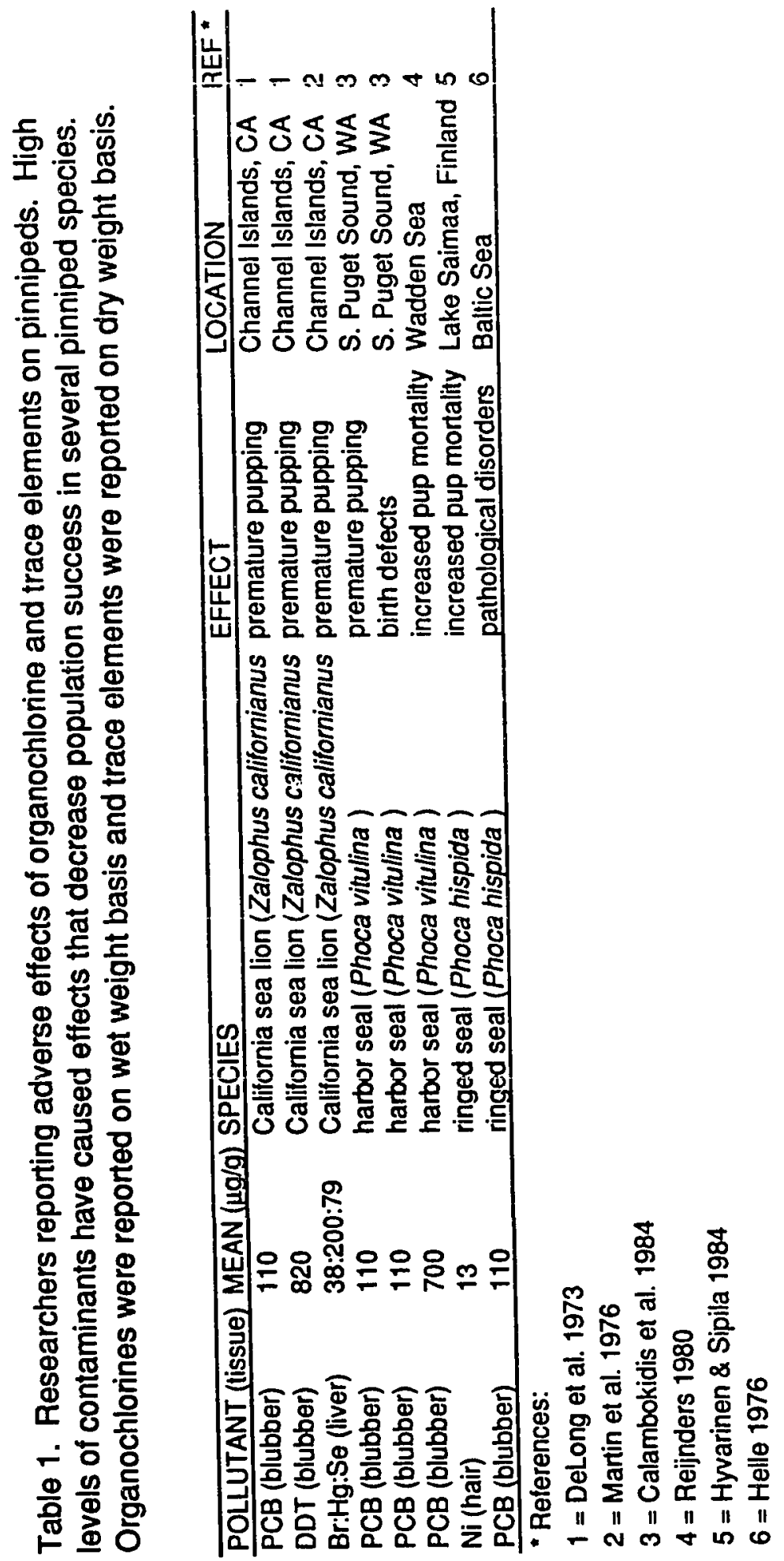


Table 2. Organochlorine and trace element concentrations in mussels (Mytilus californianus) at sites along the West coast of the United states Some samples were not analyzed (NA) or not detected (ND).

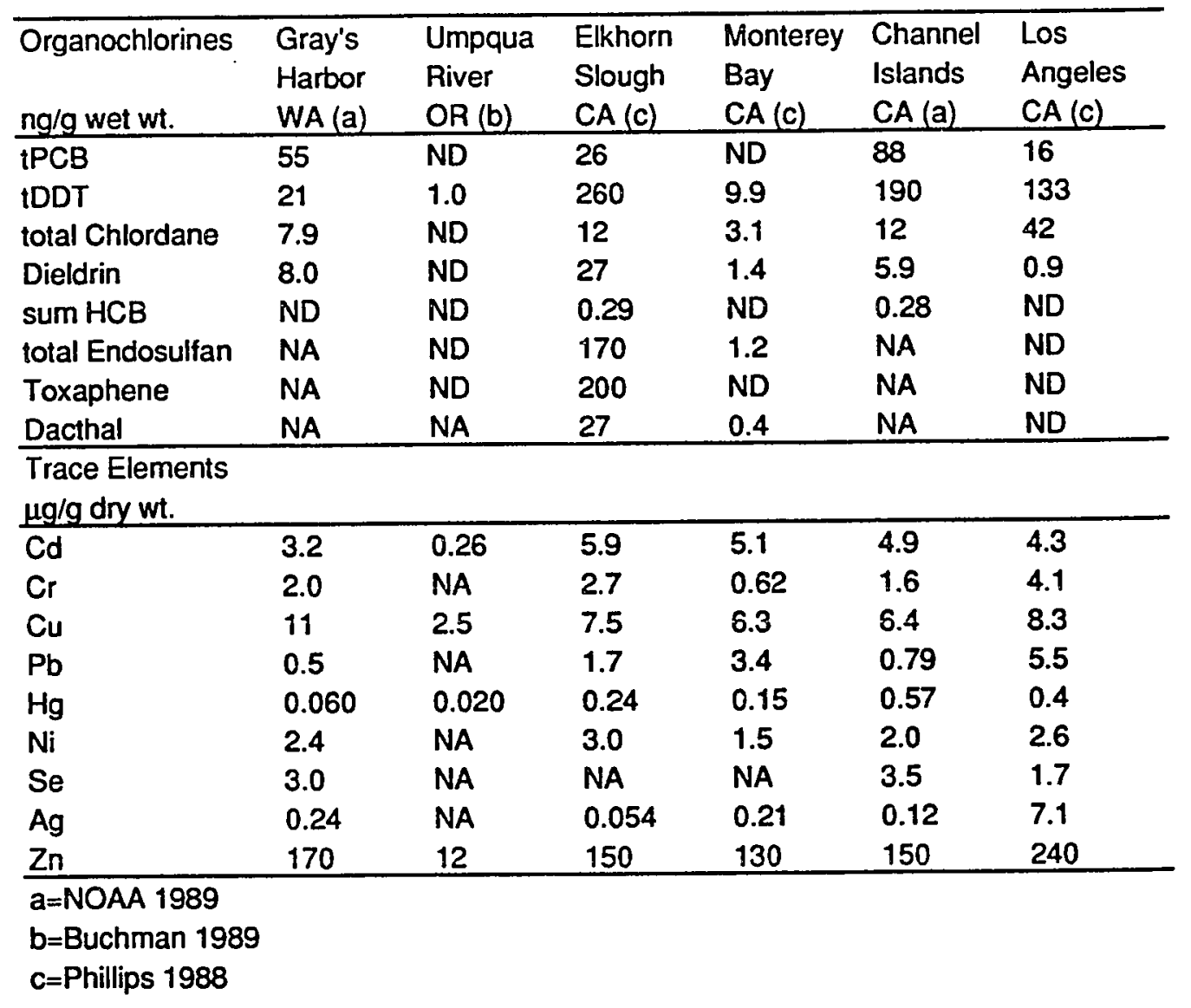


Table 3. Morphometrics of harbor seals captured at Elkhorn Slough, CA; Channel Islands, CA; Umpqua River, OR; and Gray's Harbor, WA. Sex ( male $=M$, female $=F)$, age (pup $=P$, juvenile $=J$, adult $=A)$, weight $(\mathrm{kg})$, and total iength $(\mathrm{cm})$ of each animai was recorded. Weight and length data were not available (na) at Channel islands.

\begin{tabular}{|c|c|c|c|c|c|}
\hline SAMPLE ID & LOCATION & SEX & AGE & WT (kg) & $\mathrm{TL}(\mathrm{cm})$ \\
\hline $230 \mathrm{ES}$ & Elkhorn-Daries & $F$ & A & 96 & 142 \\
\hline $231 \mathrm{ES}$ & Elkhorn-Daries & $F$ & $J$ & 36 & 132 \\
\hline $232 \mathrm{ES}$ & Elkhorn-N harbor & $M$ & A & 96 & 155 \\
\hline $233 \mathrm{ES}$ & Elkhorn-N harbor & $M$ & $J$ & 64 & 129 \\
\hline 235 ES & Elkhorn-N harbor & $M$ & A & 98 & 157 \\
\hline $237 \mathrm{ES}$ & Elkhorn-N harbor & $M$ & $J$ & 57 & 127 \\
\hline $238 \mathrm{ES}$ & Elkhorn-N harbor & $M$ & $J$ & 34 & 112 \\
\hline $239 \mathrm{ES}$ & Elkhorn-N harbor & $M$ & A & 79 & 155 \\
\hline $240 \mathrm{ES}$ & Elkhorn-N harbor & M & A & 82 & 152 \\
\hline $241 \mathrm{ES}$ & Elkhorn-N harbor & $\mathbf{F}$ & A & 86 & 147 \\
\hline 242 ES & Elkhorn-N harbor & M & J & 155 & 137 \\
\hline $201 \mathrm{Cl}$ & San Nicolas & $F$ & J & na & na \\
\hline $203 \mathrm{Cl}$ & San Nicolas & $F$ & $J$ & na & na \\
\hline $205 \mathrm{Cl}$ & San Nicolas & $F$ & J & na & na \\
\hline $207 \mathrm{Cl}$ & San Nicolas & $F$ & J & na & na \\
\hline $270 \mathrm{Cl}$ & San Miguel & $\mathbf{M}$ & A & na & na \\
\hline $271 \mathrm{Cl}$ & San Miguel & $M$ & A & na & na \\
\hline $273 \mathrm{Cl}$ & San Miguel & $F$ & $P$ & na & na \\
\hline $275 \mathrm{Cl}$ & San Miguel & $F$ & $\mathbf{P}$ & na & na \\
\hline $297 \mathrm{Cl}$ & San Miguel & $M$ & $J$ & na & na \\
\hline $22 \mathrm{OR}$ & Umpqua River & $M$ & $\mathbf{J}$ & 38 & 112 \\
\hline $25 \mathrm{OR}$ & Umpqua River & M & $J$ & 53 & 123 \\
\hline 32 OR & Umpqua River & $M$ & J & 44 & 119 \\
\hline $36 \mathrm{OR}$ & Umpqua River & $M$ & J & 46 & 123 \\
\hline 14 WA & Gray's Harbor & M & $J$ & 36 & 113 \\
\hline 17 WA & Gray's Harbor & $\mathbf{M}$ & $J$ & 37 & 108 \\
\hline
\end{tabular}


Table 4. Detection limits set by CDFG for organochlorines in harbor seal blood samples.

\begin{tabular}{cc}
\hline COMPOUND & $\begin{array}{c}\text { DETECTION LIMIT } \\
\text { fresh wt. (ng/g) }\end{array}$ \\
\hline o,p'-DDE & 5 \\
p.p'-DDE & 5 \\
o,p'-DDD & 5 \\
p.p'-DDD & 5 \\
o,p'-DDT & 5 \\
p.p'-DDT & 5 \\
trans-Chlordane & 5 \\
cis-Chlordane & 5 \\
Endosulfan I & 5 \\
Dieldrin & 5 \\
PCB-1254 & 25 \\
PCB-1260 & 25 \\
\hline
\end{tabular}


Table 5. Organochlorines analyzed in harbor seal blubber samples at Long Marine Lab, UCSC. Detection limit for all compounds was $1 \mathrm{ng} / \mathrm{g}$ fresh weight.

\begin{tabular}{llll}
\hline PCB CONGENERS & DDT COMPOUNDS & OTHER PESTICIDES \\
\hline PCB005 & PCB132 & p.p'-DDE & $\alpha-H C H$ \\
PCB008 & PCB137 & O,p'-DDE & $\beta-H C H$ \\
PCB015 & PCB138 & p.p'-DDD & $\Delta-H C H$ \\
PCB018 & PCB149 & o,p'-DDD & $\delta$-HCH \\
PCB027 & PCB151 & p.p'-DDT & Aldrin \\
PCB028 & PCB153 & O,p'-DDT & Dieldrin \\
PCB029 & PCB156 & p.p'-DDMU & Heptachlor Epoxide \\
PCB031 & PCB157 & & $\alpha$-Chlordene \\
PCB044 & PCB158 & & -Chlordene \\
PCB049 & PCB170 & & cis-Chlordane \\
PCB052 & PCB174 & & trans-Chlordane \\
PCB066 & PCB177 & & Oxychlordane \\
PCB070 & PCB180 & & sum t-Nonachlor \\
PCB074 & PCB183 & & cis-Nonachlor \\
PCB087 & PCB187 & & sum HCB \\
PCB095 & PCB189 & & Mirex \\
PCB097 & PCB194 & & \\
PCB099 & PCB195 & & \\
PCB101 & PCB200 & & \\
PCB103 & PCB201 & & \\
PCB105 & PCB203 & & \\
PCB110 & PCB206 & & \\
PCB118 & PCB209 & & \\
PCB128 & &
\end{tabular}


Table 6. Detection limits set by CDFG for trace elements in harbor seal blood, hair, liver, muscle, and vibrissae samples.

\begin{tabular}{cc}
\hline ELEMENT & $\begin{array}{c}\text { DETECTION LIMIT } \\
\text { dry } w \text { t } \mu \mathrm{g} / \mathrm{g}\end{array}$ \\
\hline $\mathrm{Cd}^{*}$ & 0.01 \\
$\mathrm{Cr}$ & 0.10 \\
$\mathrm{Cu}$ & 0.10 \\
$\mathrm{Fe}^{*}$ & 0.10 \\
$\mathrm{~Pb}^{*}$ & 0.10 \\
$\mathrm{Hg}^{*}$ & 0.03 \\
$\mathrm{Ni}^{*}$ & 0.10 \\
$\mathrm{Se}^{*}$ & 0.50 \\
$\mathrm{Ag}$ & 0.01 \\
$\mathrm{Zn}^{*}$ & 0.05 \\
\hline analyzed for red pelage comparison
\end{tabular}




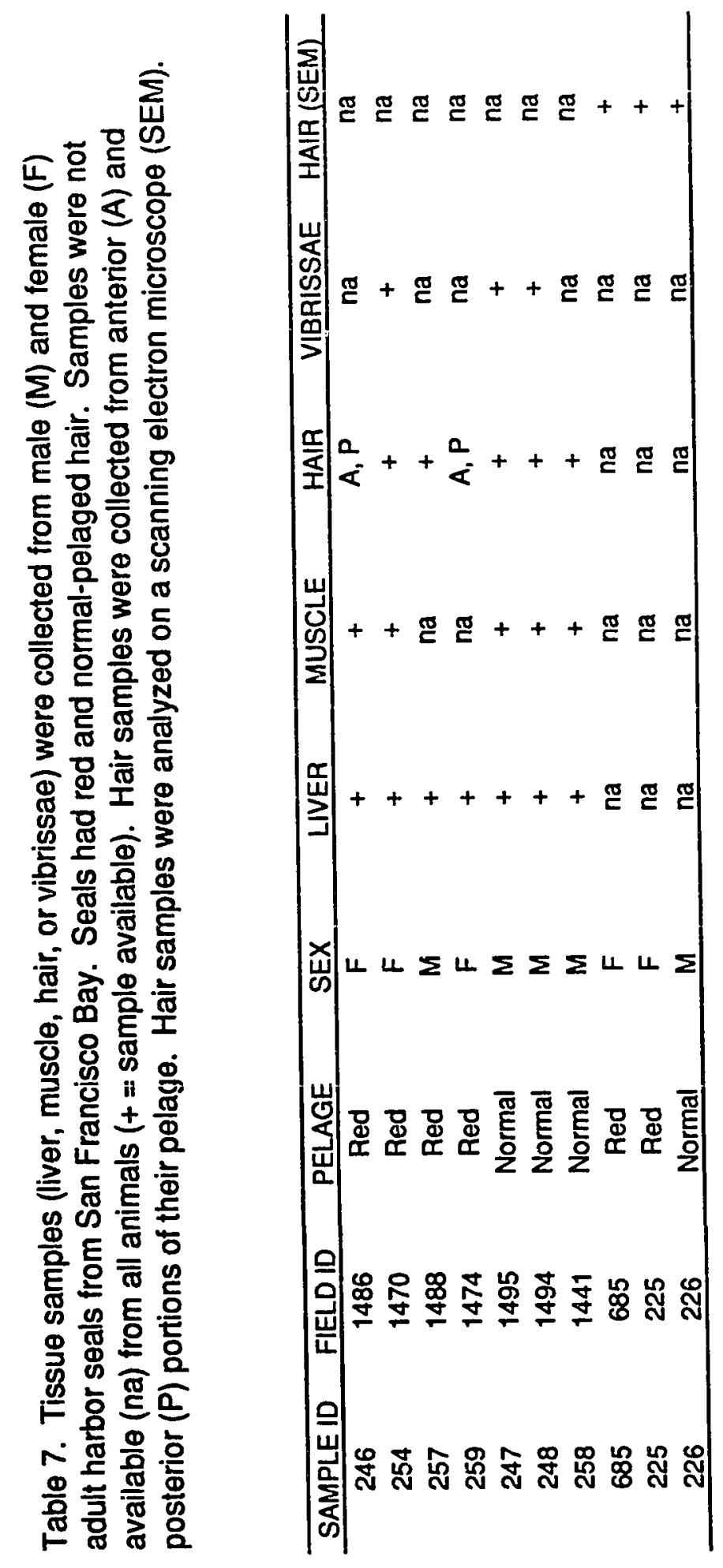


Table 8. Organochlorines analyzed in harbor seals blubber samples from Gray's Harbor, WA; Umpqua River, OR; and Elkhorn Slough, Ca. Standard error is given in parentheses.

\begin{tabular}{llll}
\hline COMPOUNDS & $\begin{array}{l}\text { Gray's Harbor } \\
\mathrm{n}=1\end{array}$ & $\begin{array}{l}\text { Umpqua River } \\
\mathrm{n}=2\end{array}$ & $\begin{array}{l}\text { Elkhorn Slough } \\
\mathrm{n}=3\end{array}$ \\
\hline Sum PCBs & 2300 & $3000(1900)$ & $3200(2200)$ \\
tDDT* & 2000 & $4100(2600)$ & $12000(5800)$ \\
$\alpha$-HCH & 19 & $16(6.4)$ & $21(22)$ \\
Dieldrin & 2.5 & $1.8(0.21)$ & $13(11)$ \\
cis-Chlordane & 1.8 & 2.0 & $4.3(3.5)$ \\
Oxychlordane & 50 & $100(68)$ & $74(47)$ \\
sum t-Nonachlor & 98 & $160(45)$ & $180(130)$ \\
sum HCB & 4.9 & $2.5(0.85)$ & $4.0(3.2)$ \\
Mirex & 6.9 & $24(16)$ & $8.7(6.4)$ \\
\hline
\end{tabular}

"tDDT = sum of DDT metabolites 
Table 9. Average organochlorine concentrations (ng/g, fresh wt.) detected in blubber samples from six juvenile harbor seals from Gray's Harbor, WA; Umpqua River, OR; and Elkhorn Slough, CA. Means and standard error reported in two significant figures. For nondetected samples, a detection iimit of $1 \mathrm{ng} / \mathrm{g}$ was used to calculate the mean. Aldrin, gamma Chlordene, PCB congeners $5,815,27$, and 66 were not detected in any samples.

\begin{tabular}{|c|c|c|c|c|c|}
\hline DDT COMPOUNDS & AVERAGE & $\overline{S E}$ & \multirow{34}{*}{$\begin{array}{l}\text { PCBS continued } \\
\text { PCB087 } \\
\text { PCB095 } \\
\text { PCB097 } \\
\text { PCB099 } \\
\text { PCB101 } \\
\text { PCB103 } \\
\text { PCB105 } \\
\text { PCB110 } \\
\text { PCB118 } \\
\text { PCB128 } \\
\text { PCB132 } \\
\text { PCB137 } \\
\text { PCB138 } \\
\text { PCB149 } \\
\text { PCB151 } \\
\text { PCB153 } \\
\text { PCB156 } \\
\text { PCB157 } \\
\text { PCB158 } \\
\text { PCB170 } \\
\text { PCB174 } \\
\text { PCB177 } \\
\text { PCB180 } \\
\text { PCB183 } \\
\text { PCB187 } \\
\text { PCB169 } \\
\text { PCB194 } \\
\text { PCB195 } \\
\text { PCB200 } \\
\text { PCB201 } \\
\text { PCB203 } \\
\text { PCB206 } \\
\text { PCB209 } \\
\end{array}$} & \multirow{10}{*}{$\begin{array}{l}\text { AVERAGE } \\
19 \\
7.8 \\
4.5 \\
200 \\
130 \\
0.99 \\
19 \\
11 \\
70\end{array}$} & \multirow{10}{*}{$\begin{array}{l}\text { IE } \\
2.8 \\
1.3 \\
0.65 \\
28 \\
20 \\
0.004 \\
3.8 \\
2.65 \\
11\end{array}$} \\
\hline p,p'-DDE & 7100 & 1300 & & & \\
\hline $0, p^{\prime}-D D E$ & 16 & 1.7 & & & \\
\hline p,p'-DDT & 350 & 57 & & & \\
\hline $0, p^{\prime}-D D T$ & 7.8 & 2.2 & & & \\
\hline p,p'-DDD & 6.9 & 1.6 & & & \\
\hline $0, p^{\prime}-D D D$ & 2.4 & 0.37 & & & \\
\hline p.p'-DDMU & 11 & 1.4 & & & \\
\hline tDDT & 7500 & 1300 & & & \\
\hline \multicolumn{3}{|c|}{ OTHER PESTICIDES } & & & \\
\hline$\overline{\alpha-H C H}$ & 19 & 3.3 & & 36 & 6.9 \\
\hline$\beta-\mathrm{HCH}$ & 8.5 & 2.5 & & 11 & 3 \\
\hline$\Delta-\mathrm{HCH}$ & 2.1 & 0.45 & & 9.1 & 1.3 \\
\hline$\delta-\mathrm{HCH}$ & 1.9 & 0.35 & & 440 & 65 \\
\hline Dieldrin & 7.4 & 2.2 & & 58 & 10 \\
\hline Heptachlor Epoxide & 4.1 & 0.82 & & 18 & 2.8 \\
\hline$\alpha$-Chlordene & 0.97 & 0.01 & & 840 & 130 \\
\hline cis-Chlordane & 2.9 & 0.69 & & 24 & 3.3 \\
\hline trans-Chlordane & 1.2 & 0.11 & & 2.3 & 0.33 \\
\hline Oxychlordane & 79 & 12 & & 20 & 3.3 \\
\hline sum t-Nonachlor & 160 & 25 & & 100 & 15 \\
\hline cis-Nonachlor & 6.1 & & & 8.8 & 1.5 \\
\hline sum $\mathrm{HCB}$ & 3.6 & 0.61 & & 23 & 3.8 \\
\hline Mirex & 14 & 2.5 & & 320 & 49 \\
\hline \multicolumn{3}{|l|}{ PCBs congeners } & & 86 & 13 \\
\hline \multirow{10}{*}{$\begin{array}{l}\text { PCB018 } \\
\text { PCB028 } \\
\text { PCB029 } \\
\text { PCB031 } \\
\text { PCB044 } \\
\text { PCB049 } \\
\text { PCB052 } \\
\text { PCB070 } \\
\text { PCB074 }\end{array}$} & 1.2 & 0.09 & & 220 & 37 \\
\hline & 2.1 & 0.239 & & 2.4 & 0.3 \\
\hline & 1.3 & 0.139 & & 41 & 6.5 \\
\hline & 8.3 & 1.7 & & 12 & 1.6 \\
\hline & 2.1 & 0.24 & & 49 & 14 \\
\hline & 11 & 1.6 & & 52 & 8.6 \\
\hline & 50 & 6.9 & & 30 & 4.5 \\
\hline & 2.8 & 0.36 & & 11 & 1.8 \\
\hline & 21 & 2.8 & & 3.1 & 0.44 \\
\hline & & & Sum PCBs & 3000 & 450 \\
\hline
\end{tabular}


Table 10. Ratios of DDT and PCB concentrations in blubber samples from six juvenile harbor seals from Grays Harbor, WA (WA); Umpqua River, OR (OR); and E!khorn Slough, CA (ES). Standard errors are given in parentheses.

\begin{tabular}{ccc}
\hline SAMPLE ID & DDT:DDE & IDDT:tPCB \\
\hline 17WA & 0.087 & 0.887 \\
25OR & 0.049 & 1.333 \\
32OR & 0.083 & 1.402 \\
233ES & 0.056 & 6.351 \\
237ES & 0.045 & 3.066 \\
238ES & 0.025 & 4.665 \\
MEAN RATIO & $0.058(0.02)$ & $2.95(2.18)$ \\
\hline
\end{tabular}


Table 11. Standard Reference Materials (SRM) analyzed with harbor seal tissues (blood - digestion 1, liver - digestion 2, muscle - digestion 2, hair digestion 3 and 4 , and vibrissae - digestion 4). Acid digested samples were analyzed for $\mathrm{Pb}, \mathrm{Ni}, \mathrm{Ag}, \mathrm{Cr}, \mathrm{Cd}, \mathrm{Cu}, \mathrm{Fe}, \mathrm{Zn}, \mathrm{Se}$, and $\mathrm{Hg}$ (some eiements were not analyzed (NA) for certain comparisons). Oyster (OYS) and Dogfish liver (DOLT) SRMs are reported with their certified range. Concentrations were reported in $\mu \mathrm{g} / \mathrm{g}$ dry weight.

\begin{tabular}{|c|c|c|c|c|c|c|c|c|c|c|}
\hline $\begin{array}{c}\text { SRM } \\
\text { OYS } \\
\text { DOLT-2 }\end{array}$ & $\begin{array}{c}\mathbf{P b} \\
0.30-0.44 \\
0.16-0.29 \\
\text { MEAN(SD) } \\
\end{array}$ & $\mathrm{n}$ & $\begin{array}{c}\mathrm{Ni} \\
1.54-3.09 \\
0.15-0.25 \\
\text { MEAN(SD) } \\
\end{array}$ & $n$ & $\begin{array}{c}\mathbf{A g} \\
1.3-2.1 \\
\\
\text { MEAN(SD) } \\
\end{array}$ & $n$ & \begin{tabular}{|c|}
$\mathbf{C r}$ \\
$0.82-2.17$ \\
$0.25-0.52$ \\
MEAN(SD) \\
\end{tabular} & n & $\begin{array}{c}\text { Cd } \\
3.2-5.21 \\
17.3-24.5 \\
\text { MEAN(SD) } \\
\end{array}$ & $\mathrm{n}$ \\
\hline Dige & & & & & & & & & & \\
\hline lean & 0.36 & 1 & $1.94(0.38)$ & 3 & 1.30 & 2 & $0.99(0.14)$ & 3 & $3.65(0.73)$ & 3 \\
\hline $\begin{array}{l}\text { DOLT Mean } \\
\text { Digestion } 2\end{array}$ & $0.22(0.02)$ & 2 & - & - & - & - & - & - & - & - \\
\hline OYS Mean & - & - & $2.02(0.20)$ & 3 & NA & - & NA & - & 4.00 & 2 \\
\hline $\begin{array}{l}\text { DOLT Mean } \\
\text { Digestion } 3\end{array}$ & $0.21(0.05)$ & 3 & - & - & NA & - & NA & - & $20.90(1.48)$ & 2 \\
\hline OYS Mean & - & - & $2.41(0.49)$ & 3 & $1.9(0.02)$ & 3 & $1.16(0.03)$ & 2 & $4.37(0.18)$ & 3 \\
\hline $\begin{array}{l}\text { DOLT Mean } \\
\text { Diqestion } 4\end{array}$ & & 1 & & - & - & - & - & - & - & - \\
\hline OYS Mean & $0.31(0.01)$ & 2 & $2.37(0.35)$ & 3 & NA & - & NA & - & $4.78(0.30)$ & 3 \\
\hline Mean & - & - & - & - & NA & - & NA & - & - & - \\
\hline $\begin{array}{c}\text { OYS } \\
\text { DOLT-2 }\end{array}$ & \begin{tabular}{|c}
$\mathrm{Cu}$ \\
$52.7-81.2$ \\
$21.0-30.9$ \\
MEAN(SD) \\
\end{tabular} & $n$ & $\begin{array}{c}\text { Fe } \\
445-627 \\
898-1320 \\
\text { MEAN(SD) } \\
\end{array}$ & & $\begin{array}{c}\mathrm{Zn} \\
657-1020 \\
66.6-106 \\
\text { MEAN(SD) } \\
\end{array}$ & & \begin{tabular}{|c} 
Se \\
$1.67-2.82$ \\
$4.73-7.53$ \\
MEAN(SD)
\end{tabular} & $n$ & $\begin{array}{c}\mathrm{Hg} \\
0.049-0.082 \\
1.61-2.40 \\
\text { MEAN(SD) } \\
\end{array}$ & n \\
\hline Digestion 1 & & & & & & & & & & \\
\hline OYS Mean & $68.06(2.64)$ & 3 & $530(28)$ & 2 & - & - & $2.34(0.16)$ & 2 & $0.05(0.01)$ & 3 \\
\hline $\begin{array}{l}\text { DOLT Mean } \\
\text { Digestion } 2\end{array}$ & - & - & $1051(82)$ & 2 & $101(6.9)$ & 3 & 4.81 & 1 & 2.29 & 1 \\
\hline OYS Mean & NA & - & 521 & 2 & - & - & $2.01(0.09)$ & 2 & 0.30 & 1 \\
\hline $\begin{array}{l}\text { DOLT Mean } \\
\text { Digestion } 3\end{array}$ & NA & - & $1069(88)$ & 2 & $94.9(3.12)$ & 2 & - & - & - & - \\
\hline OYS Mean & 79 & 1 & $564(14)$ & 2 & - & - & $2.63(0.05)$ & 2 & $0.49(0.05)$ & 2 \\
\hline $\begin{array}{l}\text { DOLT Mean } \\
\text { Digestion } 4\end{array}$ & 30.28 & 1 & $1062(28)$ & 2 & $92.8(1.3)$ & 3 & & - & - & - \\
\hline OYS Mean & NA & - & $582(7)$ & 2 & - & - & $2.48(0.72)$ & 2 & $0.55(0.04)$ & 3 \\
\hline DOLT Mean & NA & - & $1080(9)$ & 2 & $95(4.59)$ & 3 & $4.11(0.01)$ & 2 & - & - \\
\hline
\end{tabular}


Table 12. Trace element concentrations ( $\mu \mathrm{g} / \mathrm{g}$, dry wt.) were analyzed in blood and hair of harbor seals from Grays Harbor, WA (GH); Umpqua River, OR (UR); Elkhorn Slough, CA (ES); and Channel Is., CA (Cl). These values were compared between age classes [aduits (A) and juveniles (j)j, sexes (maies and females), and among four sites (standard error in parentheses). T-test and ANOVA p-values of less than $0.05^{*}$ indicate significant differences. Power of these comparisons were calculated. Because of insufficient data, not all all comparisions were analyzed (na).

\begin{tabular}{|c|c|c|c|c|c|c|c|c|c|c|}
\hline \multirow[b]{3}{*}{ ELEMENT } & \multirow{3}{*}{$\begin{array}{c}\text { BLOOD } \\
\text { MEAN (SE) }\end{array}$} & \multirow[b]{3}{*}{ n } & \multicolumn{4}{|c|}{ P-VALUES } & \multicolumn{4}{|c|}{ POWER (\%) } \\
\hline & & & \multirow{2}{*}{$\begin{array}{c}\text { AGE } \\
\mathrm{J}: A\end{array}$} & \multicolumn{2}{|c|}{ SEX } & \multirow{2}{*}{$\begin{array}{c}\text { ALL } \\
\text { SITES }\end{array}$} & \multirow{2}{*}{$\begin{array}{c}\text { AGE } \\
J: A\end{array}$} & \multicolumn{2}{|c|}{ SEX } & \multirow{2}{*}{$\begin{array}{c}\text { ALL } \\
\text { SITES }\end{array}$} \\
\hline & & & & ES & $\mathrm{Cl}$ & & & ES & $\mathrm{Cl}$ & \\
\hline $\mathrm{Cd}$ & $0.020(0.002)$ & 9 & na & & na & na & na & na & na & na \\
\hline $\mathrm{Cr}$ & ND & & na & & na & na & na & na & na & na \\
\hline $\mathrm{Cu}$ & $3.3(0.18)$ & 23 & $0.021^{*}$ & 0.458 & 0.275 & 0.952 & na & 12 & 15 & $<10$ \\
\hline $\mathrm{Fe}$ & $3100(200)$ & 23 & $0.036^{*}$ & 0.685 & 0.443 & 0.878 & na & $<10$ & 10 & na \\
\hline $\mathrm{Pb}$ & ND & & na & & na & na & na & na & na & na \\
\hline $\mathrm{Hg}$ & $0.61(0.15)$ & 23 & na & & na & na & na & na & na & na \\
\hline $\mathrm{Ni}$ & ND & & na & & na & na & na & na & na & na \\
\hline $\mathrm{Se}$ & $3.9(0.25)$ & 23 & $0.05^{*}$ & 0.690 & 0.507 & 0.502 & na & $<10$ & 25 & $<10$ \\
\hline $\mathrm{Ag}$ & $0.030(0.002)$ & 6 & na & & na & na & na & na & na & na \\
\hline \multirow[t]{2}{*}{$\mathrm{Zn}$} & $29(1.4)$ & 23 & 0.02 & 0.957 & 0.287 & 0.980 & na & $<10$ & 17 & na \\
\hline & HAIR & & & & & & & & & \\
\hline $\mathrm{Cd}$ & $1.9(0.72)$ & 11 & 0.100 & 0.540 & & & na & na & & \\
\hline $\mathrm{Cr}$ & 19(3.9) & 11 & 0.992 & 0.956 & & & $<10$ & $<10$ & & \\
\hline $\mathrm{Cu}$ & 26 & 11 & 0.980 & 0.624 & & & $<10$ & $<10$ & & \\
\hline $\mathrm{Fe}$ & $3600(750)$ & 11 & 0.067 & 0.776 & & & $<10$ & $<10$ & & \\
\hline $\mathrm{Pb}$ & $3.6(1.5)$ & 11 & 0.725 & 0.708 & & & $<10$ & $<10$ & & \\
\hline $\mathrm{Hg}$ & $35(4.5)$ & 11 & na & na & & & na & na & & \\
\hline $\mathrm{Ni}$ & $13(2.5)$ & 11 & 0.702 & 0.492 & & & $<10$ & $<10$ & & \\
\hline Se & $4.4(0.63)$ & 11 & 0.240 & 0.370 & & & 15 & 19 & & \\
\hline $\mathbf{A g}$ & $0.080(0.01)$ & 11 & 0.460 & 0.980 & & & 99 & 0 & & \\
\hline $\mathrm{Zn}$ & $120(290)$ & 11 & 0.424 & 0.606 & & & $<10$ & $<10$ & & \\
\hline
\end{tabular}



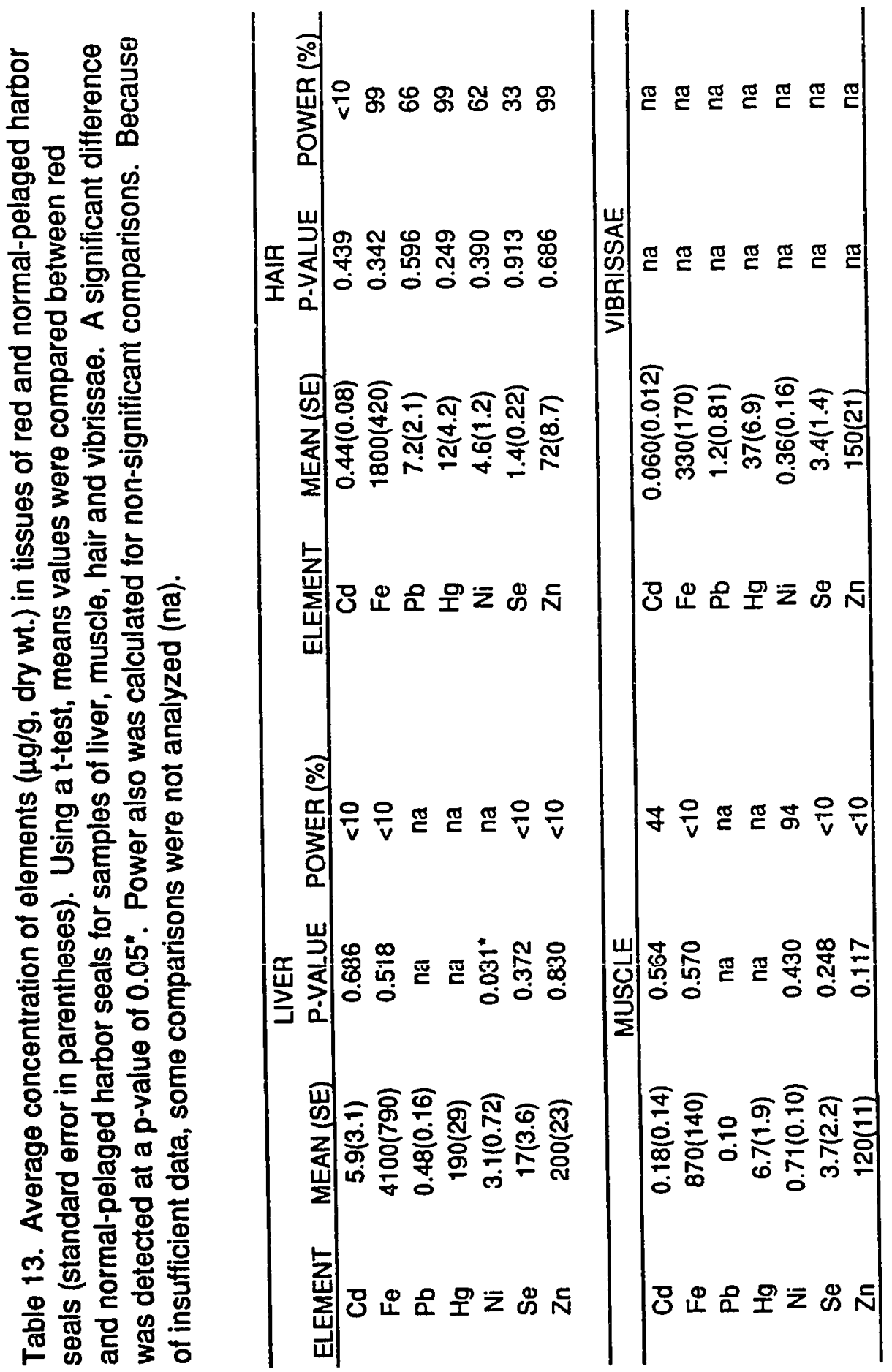
Table 14. Average element concentrations ( $\mu \mathrm{g} / \mathrm{g}$, dry wt.) of anterior and posterior hair from red-pelaged harbor seals (standard error in parentheses). These two samples were compared using a t-test.

\begin{tabular}{llll}
\hline ELEMENT & ANTERIOR HAIR & POSTERIOR HAIR & P-VALUE \\
\hline $\mathrm{Cd}$ & $0.37(0.15)$ & $0.49(0.13)$ & 0.636 \\
$\mathrm{Fe}$ & $2300(470)$ & $1800(1100)$ & 0.596 \\
$\mathrm{~Pb}$ & $9.7(4)$ & $6.1(2.9)$ & 0.592 \\
$\mathrm{Hg}$ & $7.1(2.8)$ & $5.3(1.2)$ & 0.695 \\
$\mathrm{Ni}$ & $3.6(100)$ & $4.7(2.3)$ & 0.626 \\
$\mathrm{Se}$ & $1.6(0.36)$ & $1.2(0.12)$ & 0.517 \\
$\mathrm{Zn}$ & $71(13)$ & $70(16)$ & 0.976 \\
\hline
\end{tabular}


Table 15. Elements in hair samples from red and normal pelage were analyzed with a SEM X-ray. Elements were reported on a harbor seals percentage by molecular weight basis. Samples included red hair $(n=2)$, normal hair $(n=1)$, and red hair stripped in ascorbate acid $(n=1)$.

\begin{tabular}{cccc}
\hline ELEMENT & RED HAIR & NORMAL HAIR & STRIPPED RED HAIR \\
\hline $\mathrm{S}$ & $46-49$ & 11 & $93-95$ \\
$\mathrm{Fe}$ & $14-30$ & 31 & $0-2$ \\
$\mathrm{Al}$ & $2-3$ & 10 & 2 \\
$\mathrm{Si}$ & $1-4$ & 7 & 0 \\
$\mathrm{P}$ & $1-4$ & 0 & 0 \\
$\mathrm{Mg}$ & $1-3$ & 0 & $0-1$ \\
$\mathrm{~K}$ & $1-3$ & 4 & 0 \\
$\mathrm{Ca}$ & $4-7$ & 5 & 2 \\
$\mathrm{Cl}$ & $1-23$ & 32 & 0 \\
\hline
\end{tabular}




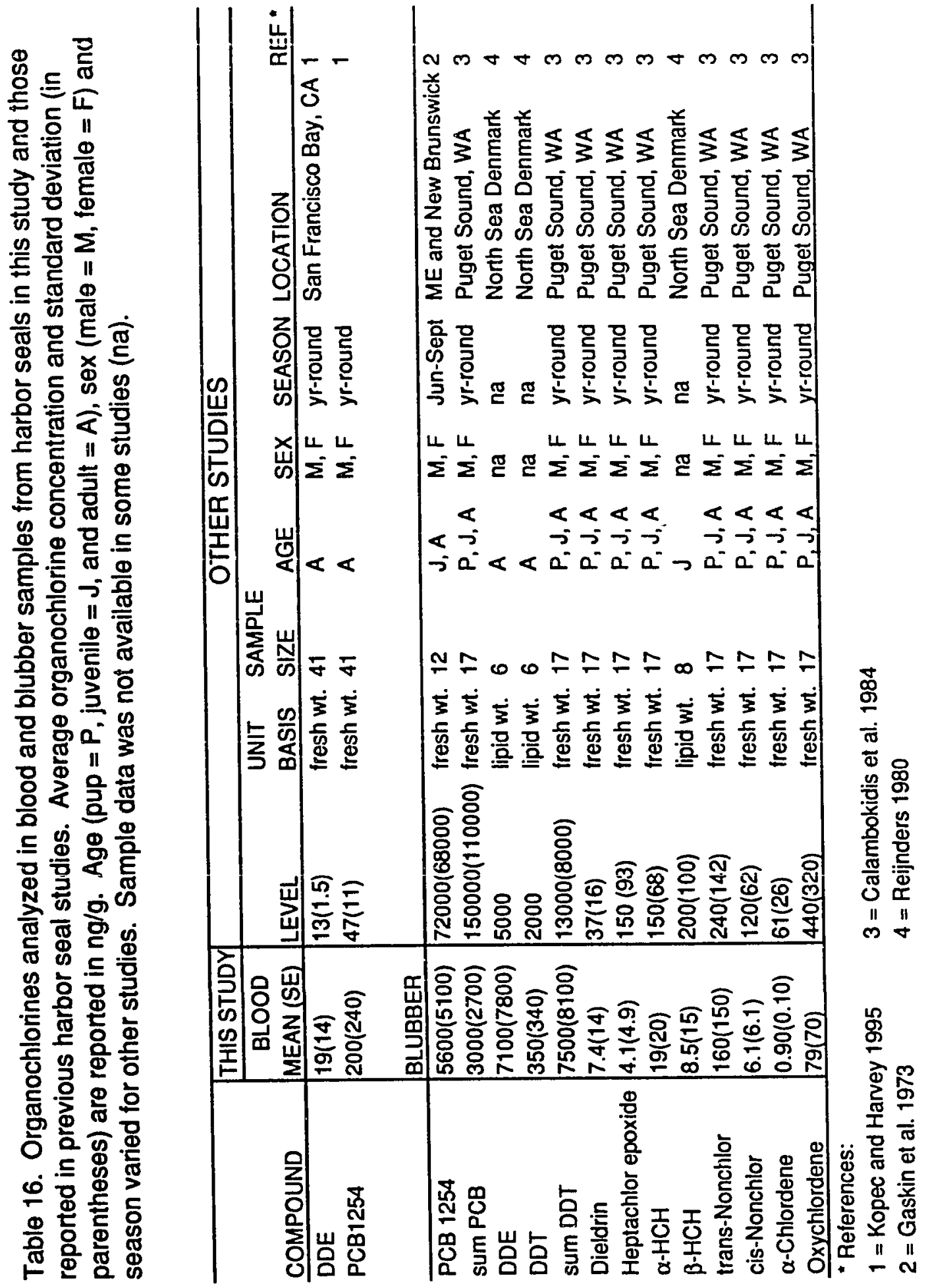




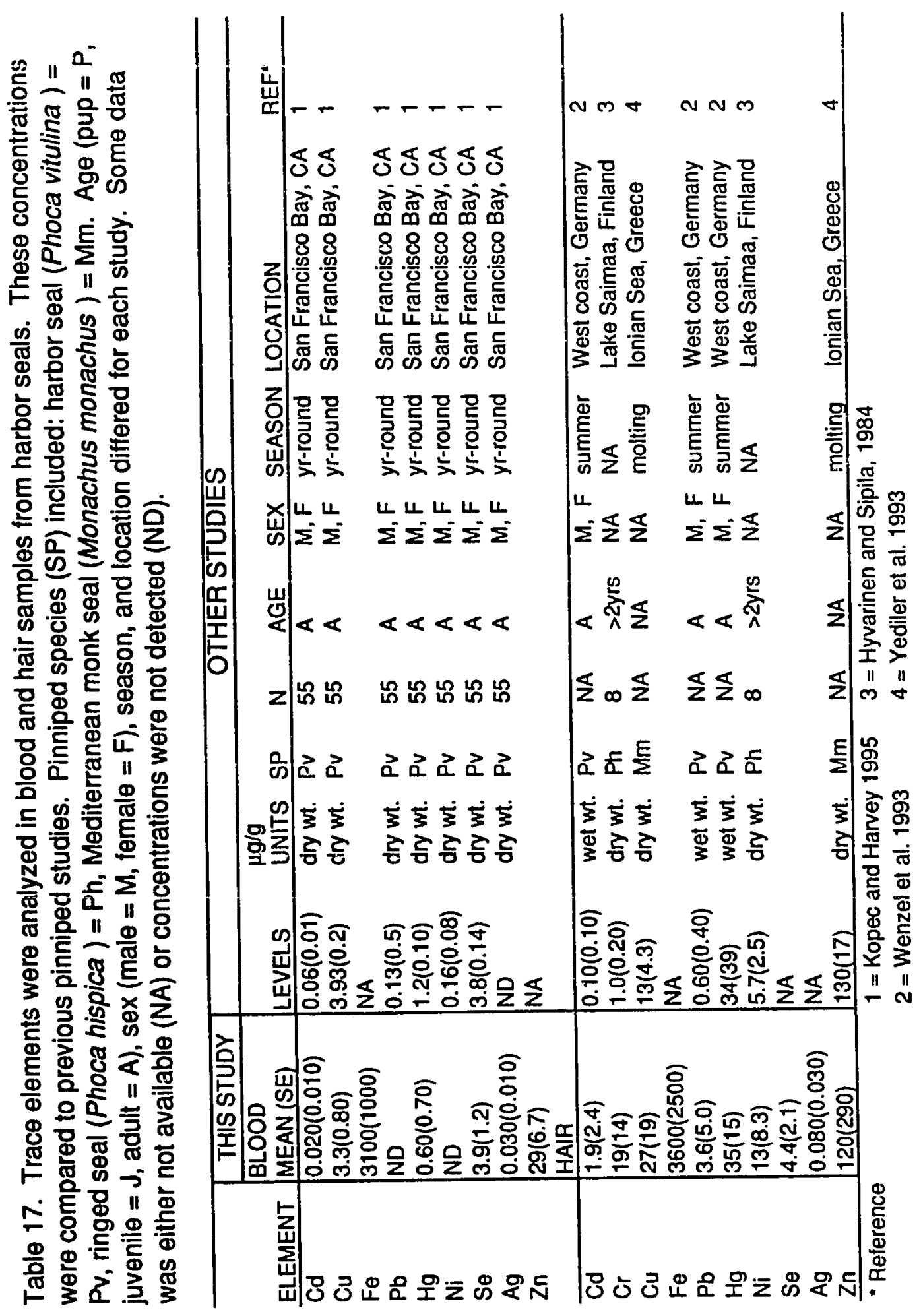



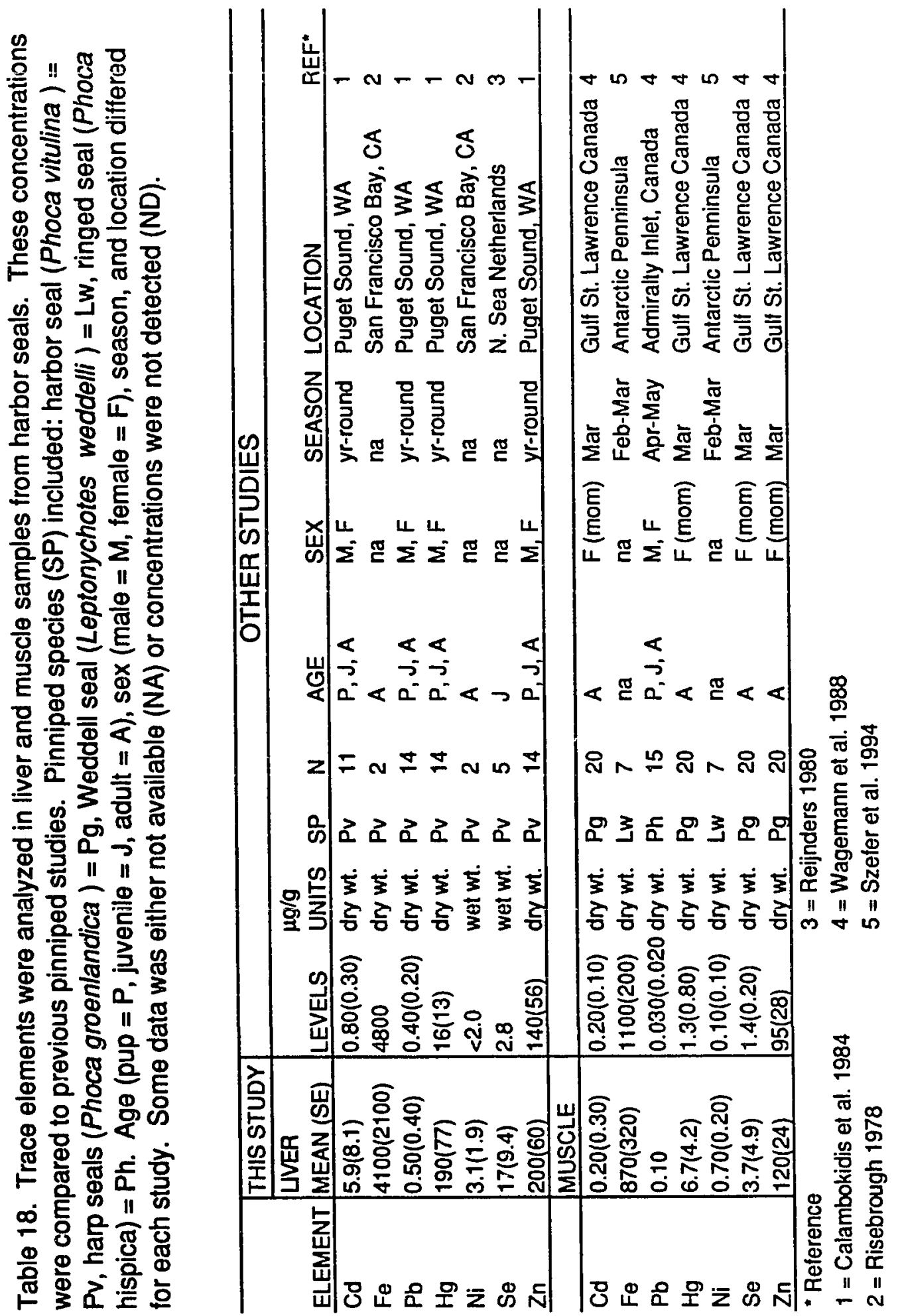


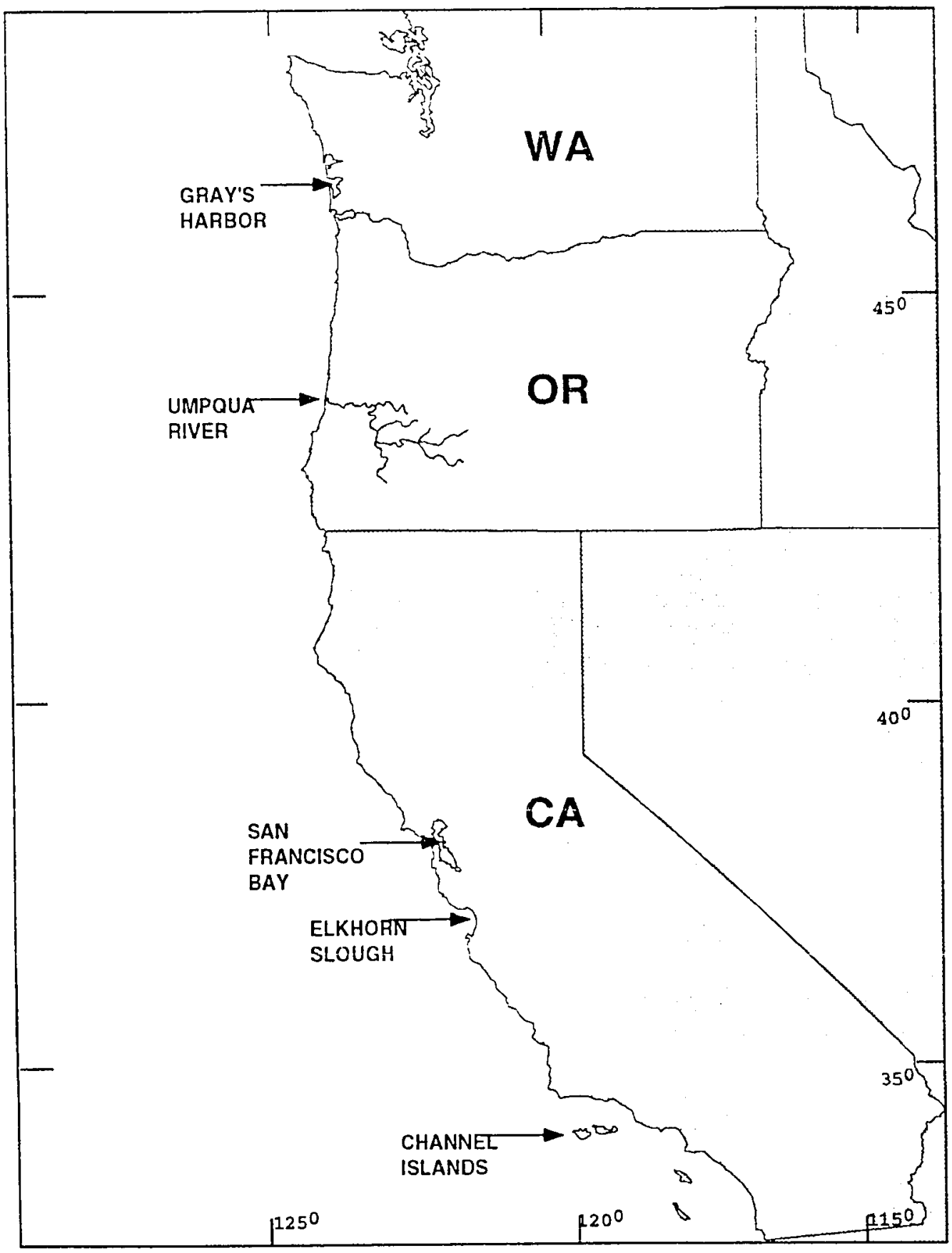

Fig. 1. Locations where samples were collected from live harbor seals captured at Gray's Harbor, WA; Umpqua River, OR; Elkhorn Slough, CA; and Channel Islands, CA. Samples also were collected from stranded seals in San Francisco Bay, CA. 

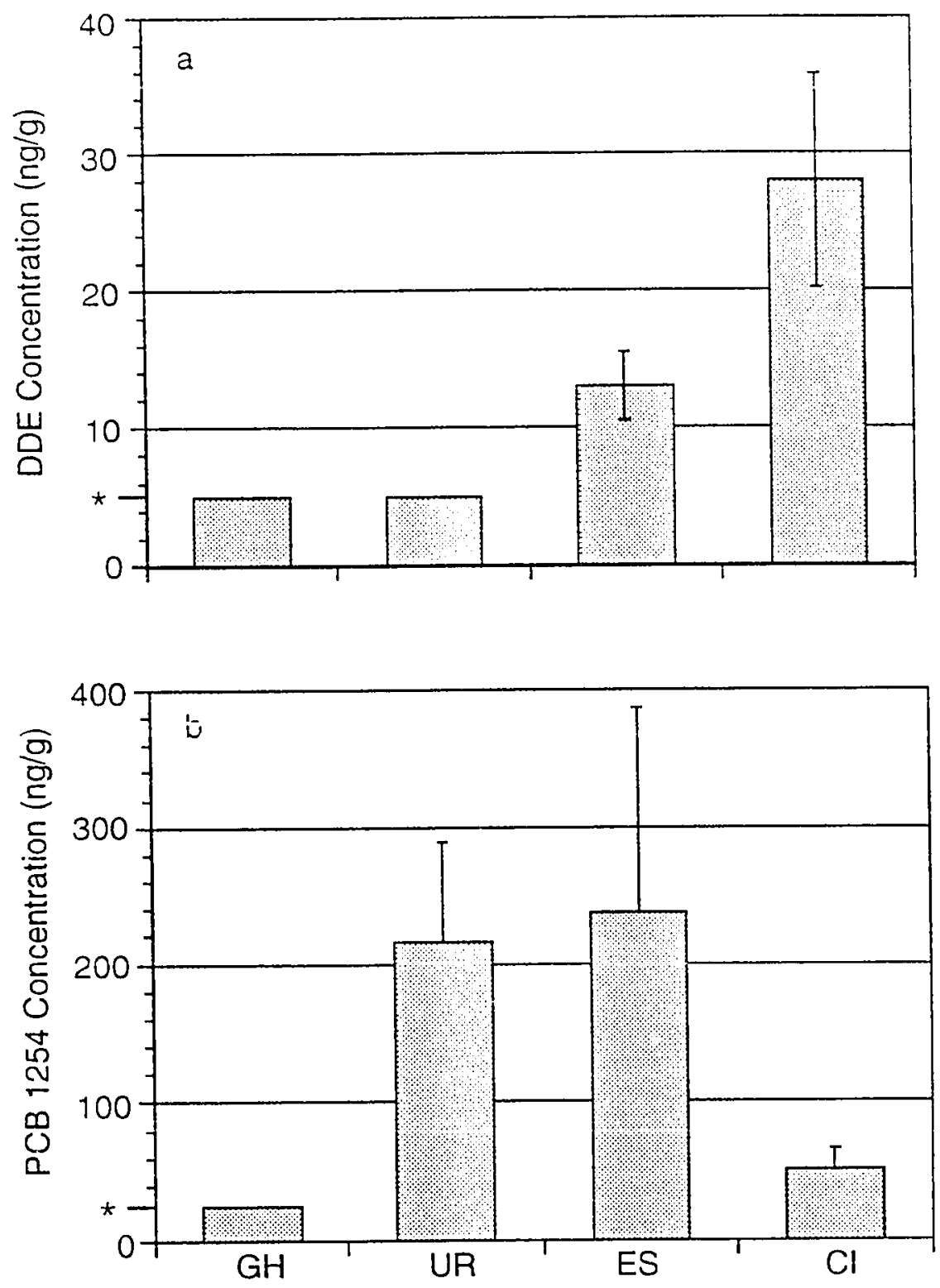

Fig. 2. Mean blood DDE (a) and PCB 1254 (b) concentrations (ng/g) among juvenile harbor seals from Gray's Harbor, WA; Umpqua River OR; Elkhorn Slough,CA; and Channel Islands, CA ( $p=0.051)$. Vertical lines above mean bars represent one standard error. Concentrations below detection limits $\left(^{*}\right)$ were not detected. 


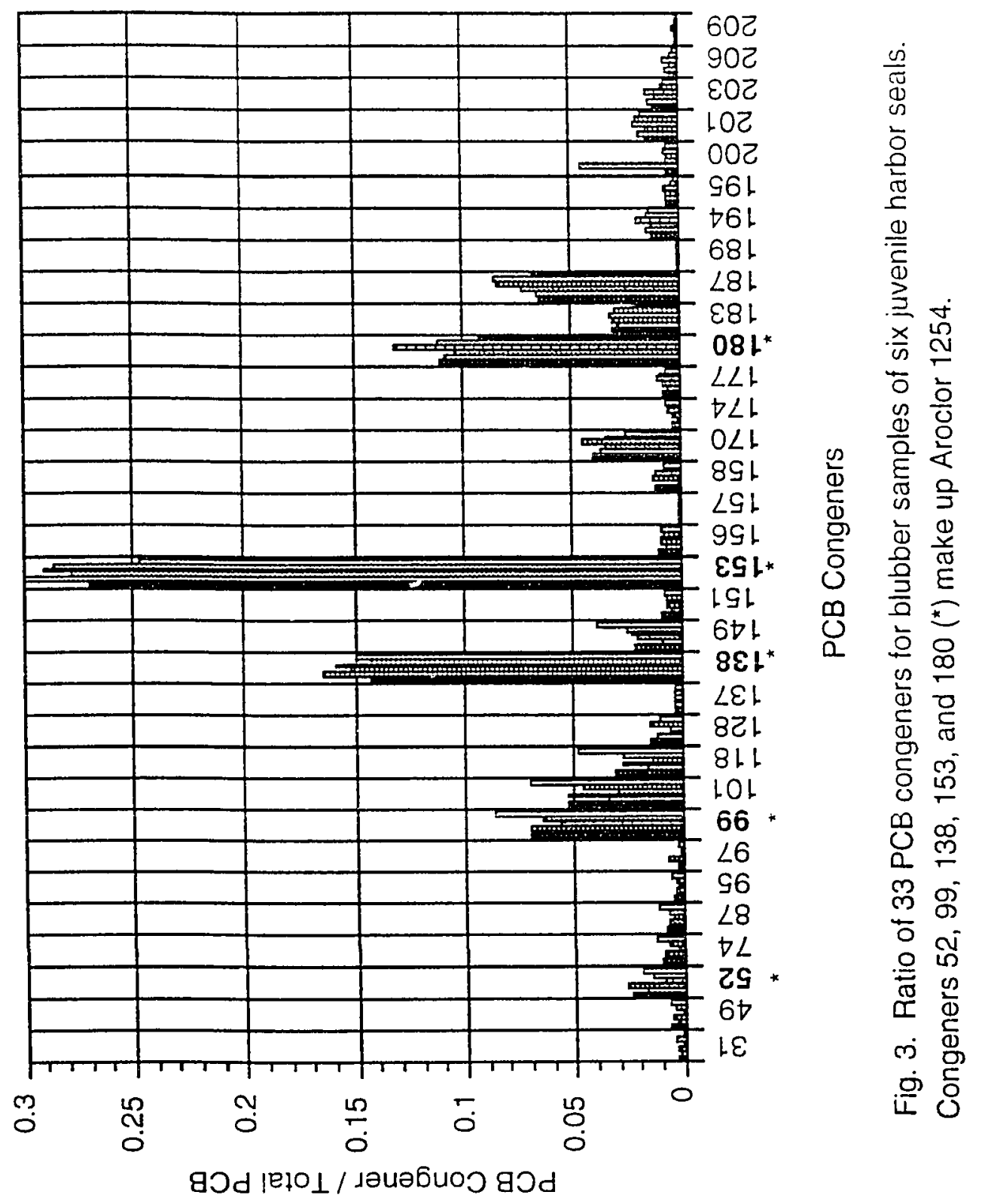



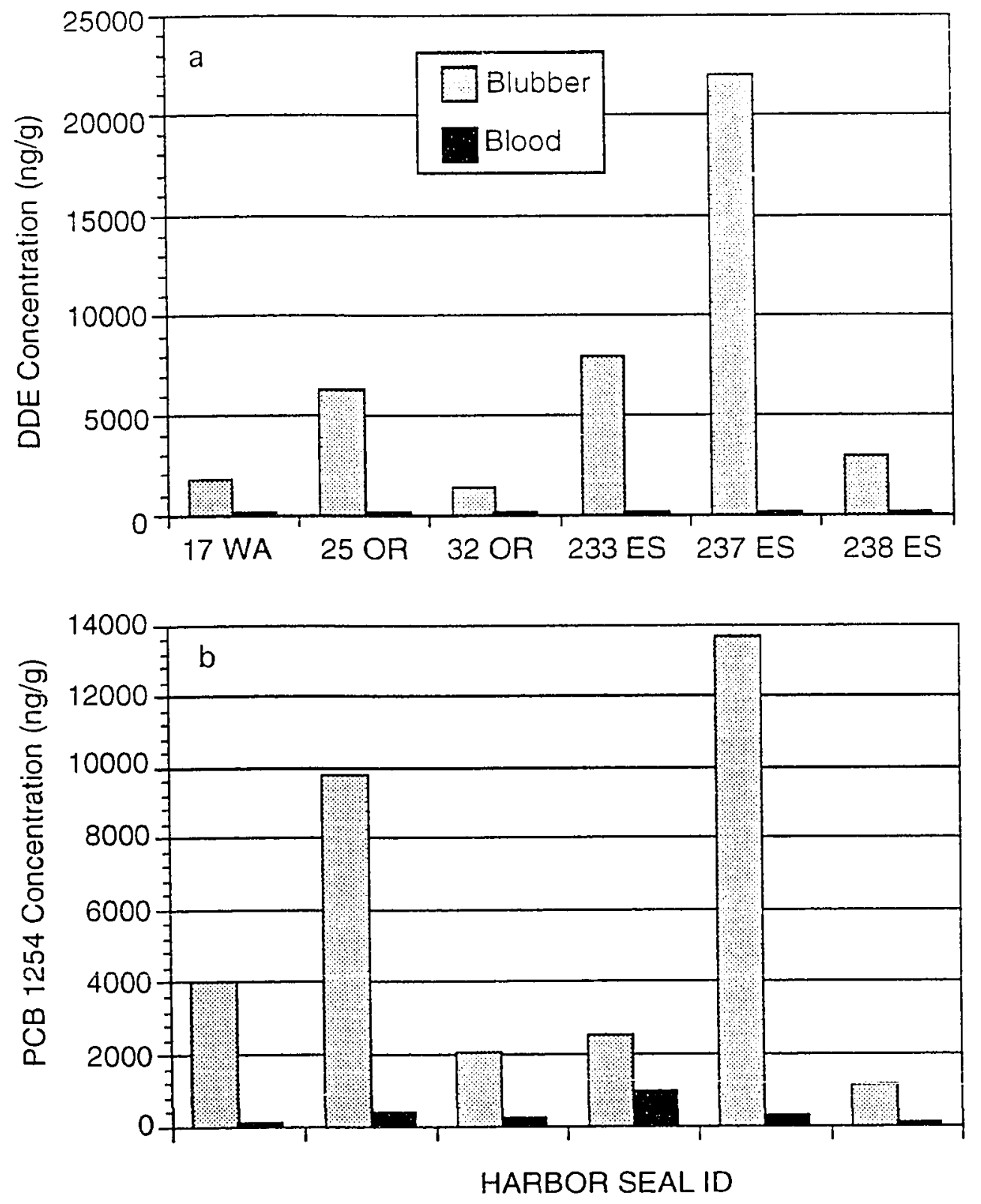

Fig. 4. Blubber and blood concentrations in $n g / g$ of DDE (a) and PCB 1254 (b) from juvenile harbor seals captured at Gray's Harbor, WA; Umpqua River, OR; and Elkhorn Slough, CA. 

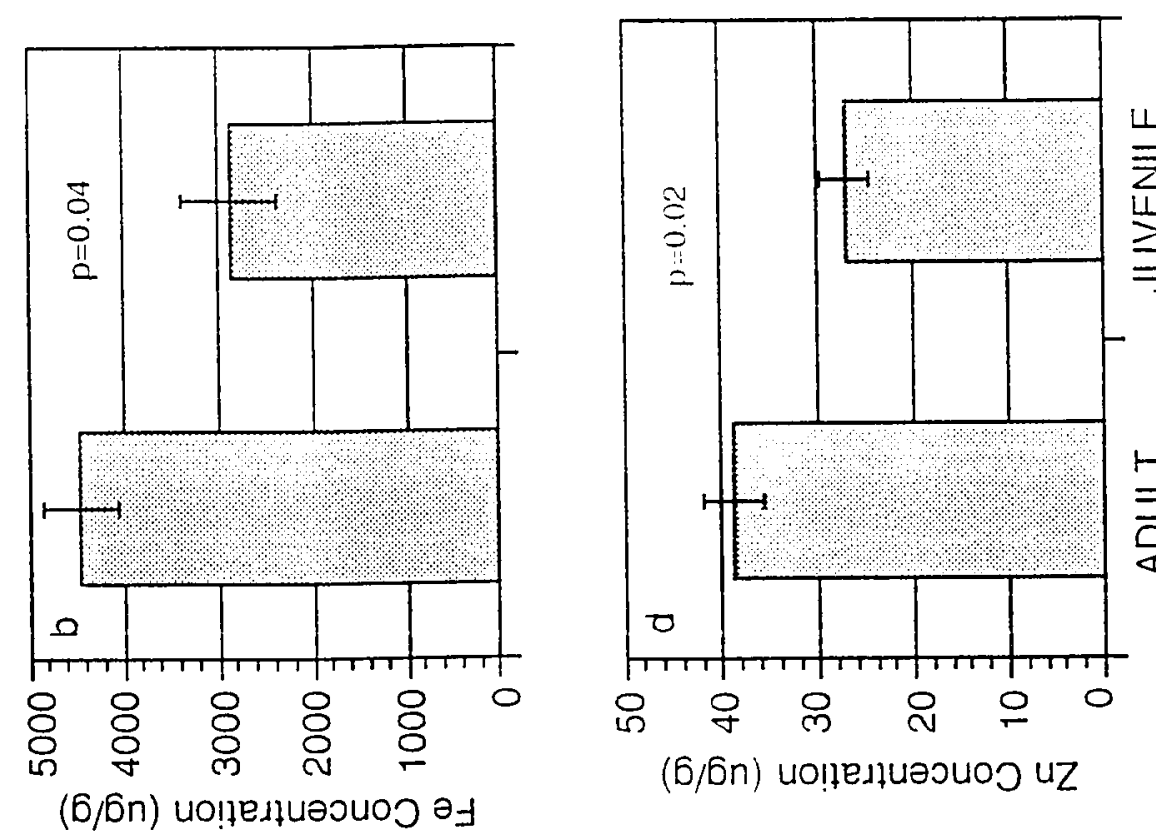

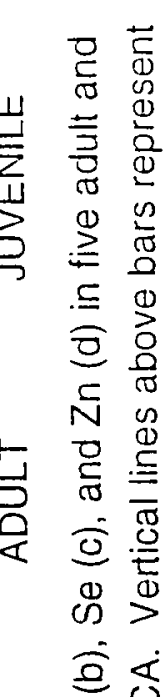
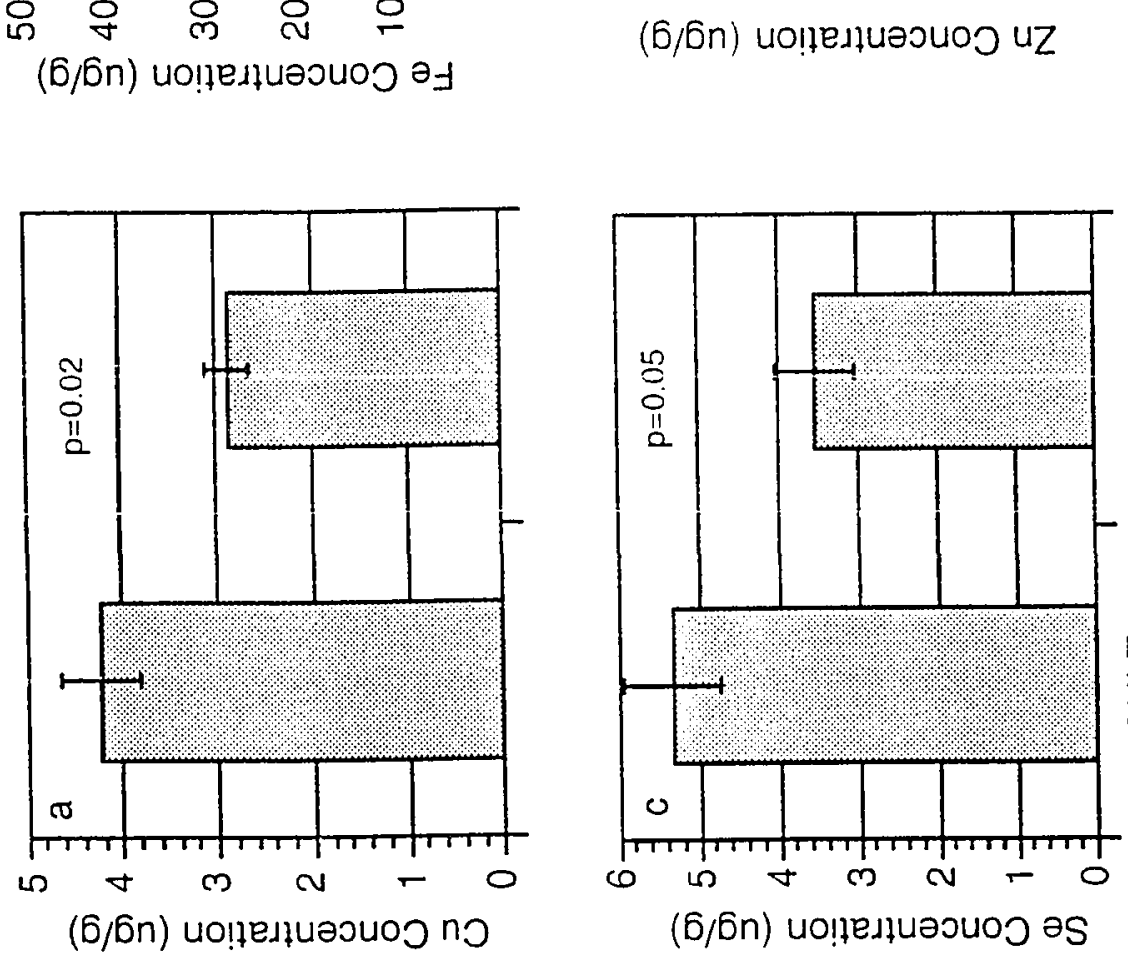

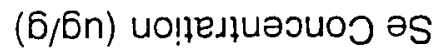

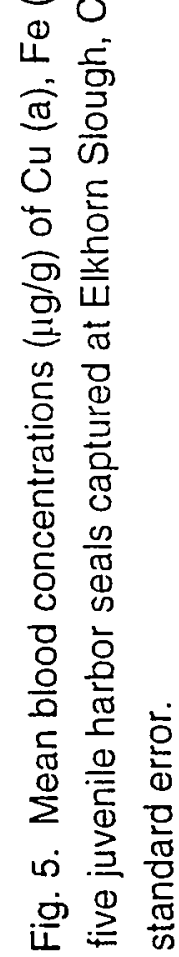




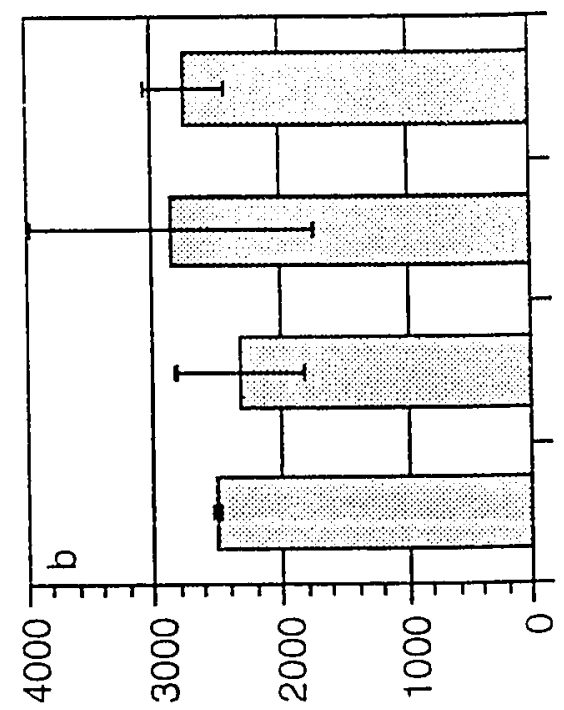

(6/6n) uo!fedtuəouoว

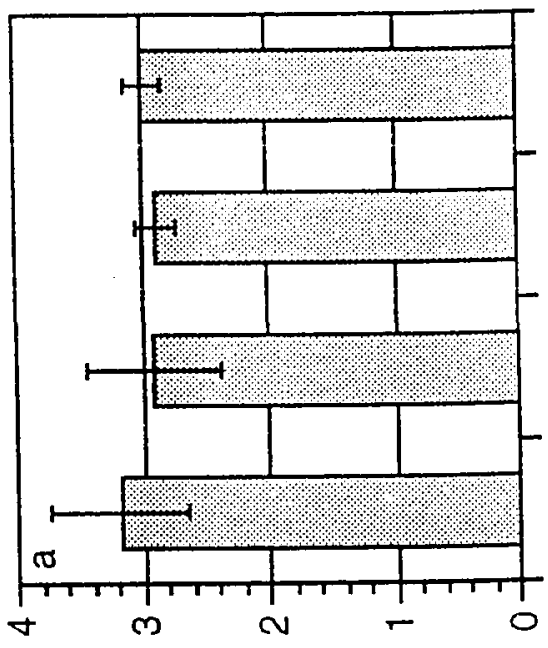

(6/5̂n) uo!tedfuəouos no

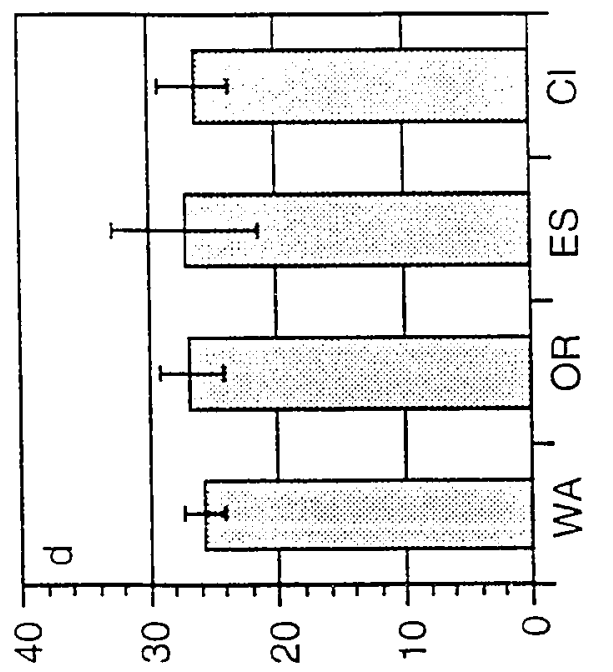

(6/6n) บo!ne

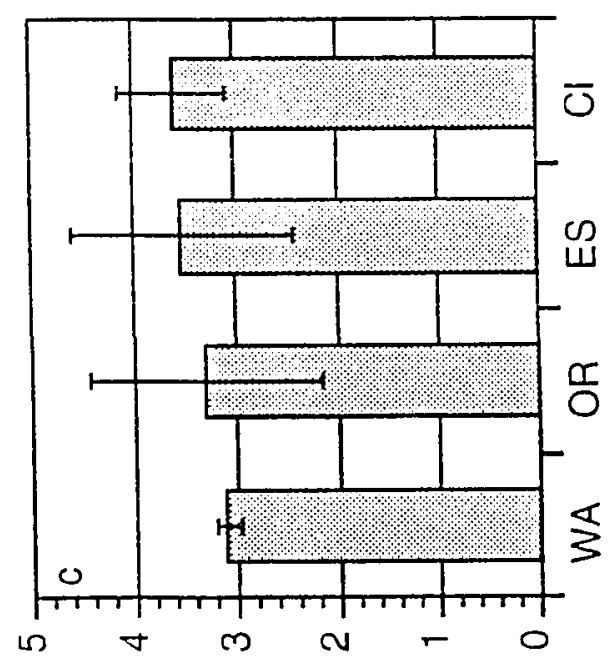

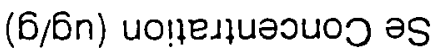

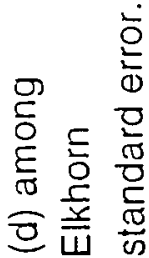

N

무용

ธ बे

$\dot{0} \geqq \stackrel{0}{\Phi}$

(1) $\frac{\omega}{7}$

凹

을요 잉

a 5

$4 \dddot{x}$

$-\sum^{2}$

更

उ 응

诃

का $\frac{1}{\infty} \stackrel{5}{>}$

일 त. 듕 두

을 吕

气

ญ ํㅡㅇ

ठ ํำ

융

음

등ㅇㄴ 은

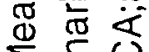

$\sum \frac{\Phi}{\omega}$

के

桴引 응 


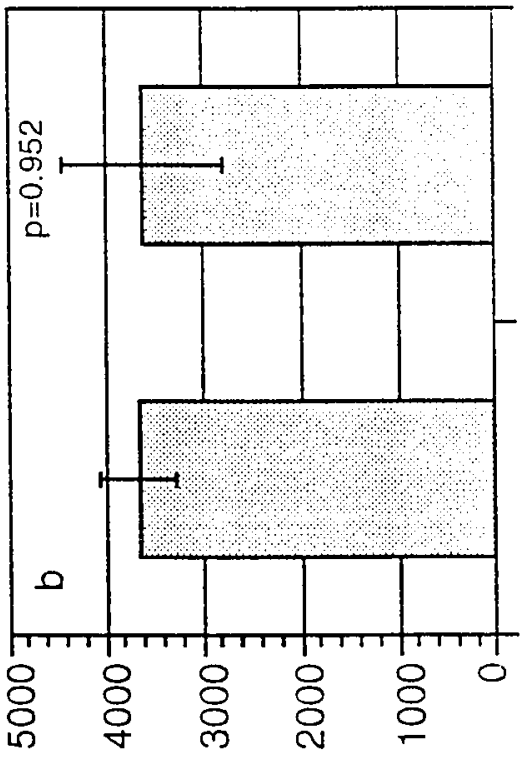

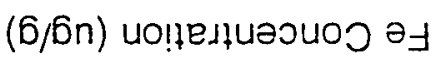

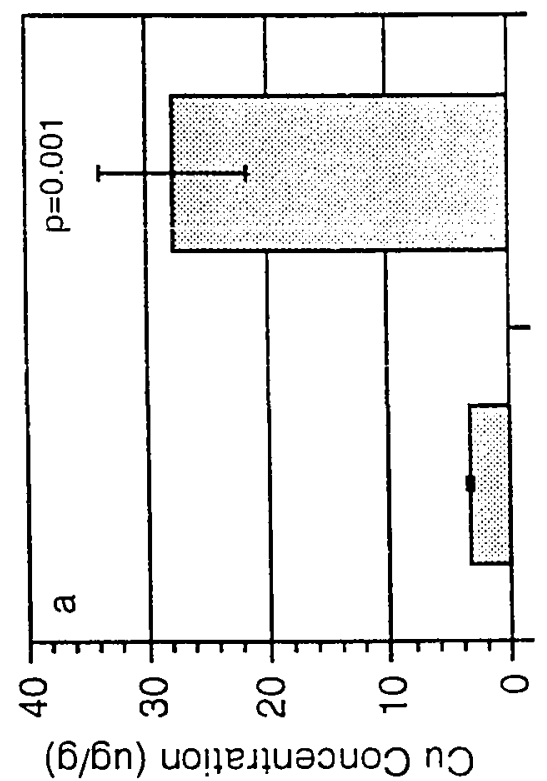

(6/6n) uo!nestuəouoo no

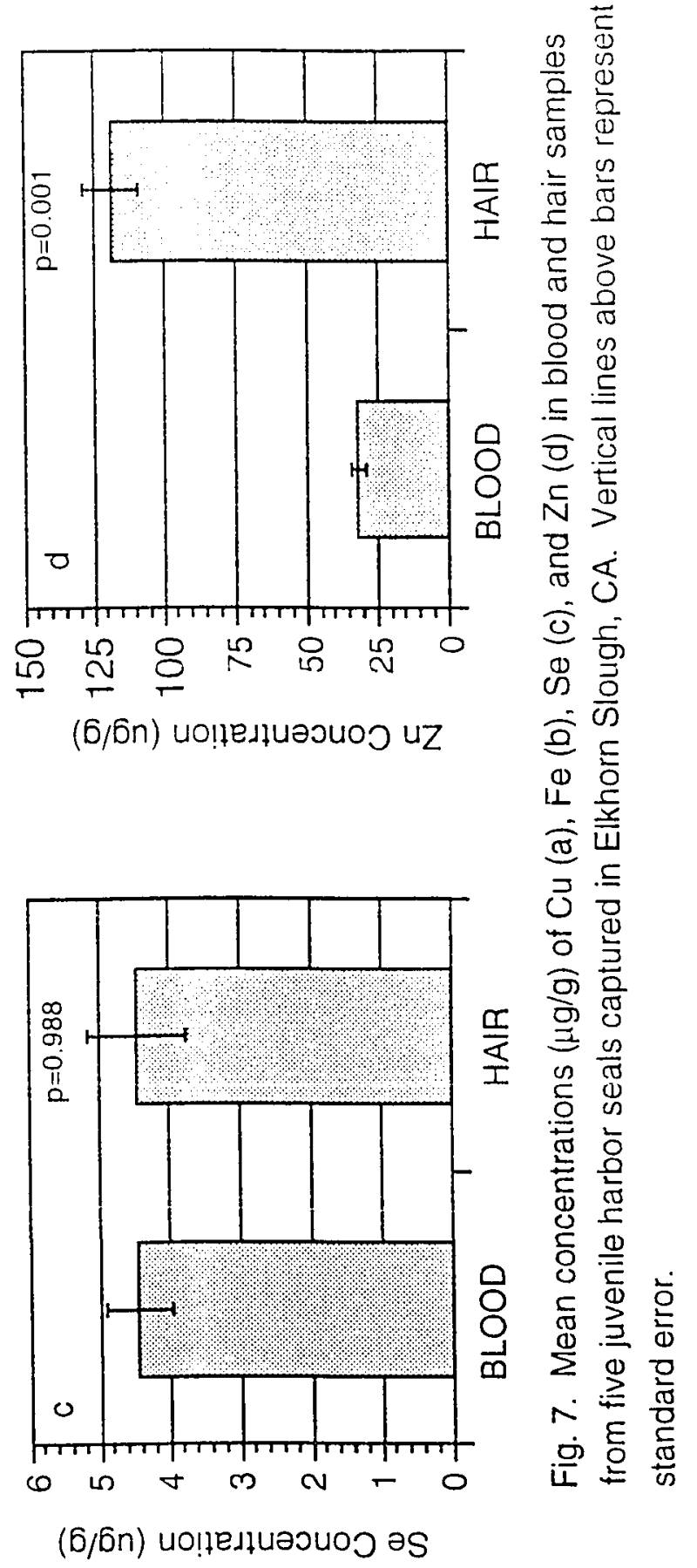

(6/6n) uo!tedłuəouoว əS 

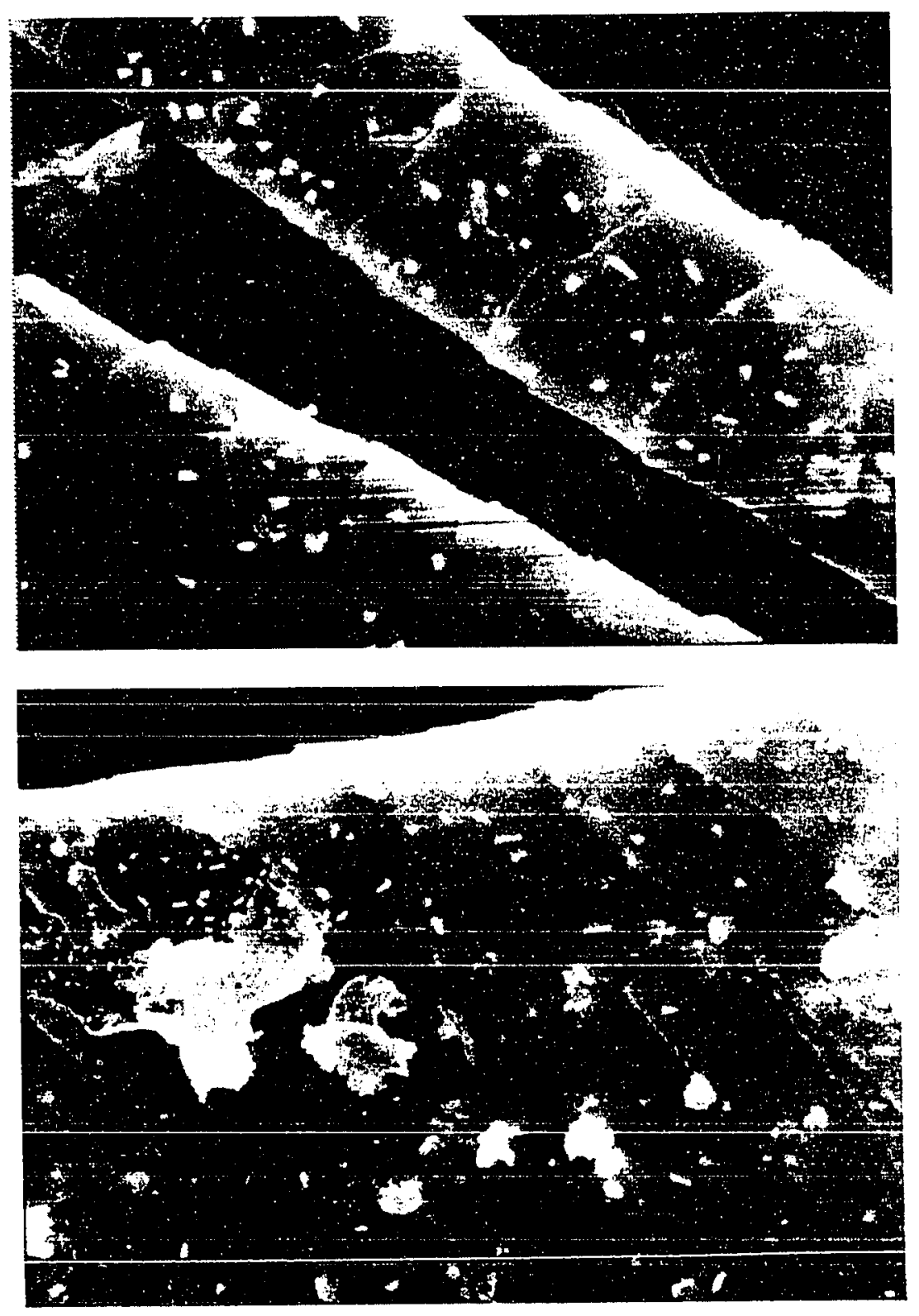

Fig. 8. Hair from a normal-pelaged harbor seal was analyzed on a SEM. Hair tips (upper) and hair shafts (lower) had symetrical cutical scaling and no accumulated particulate matter. 

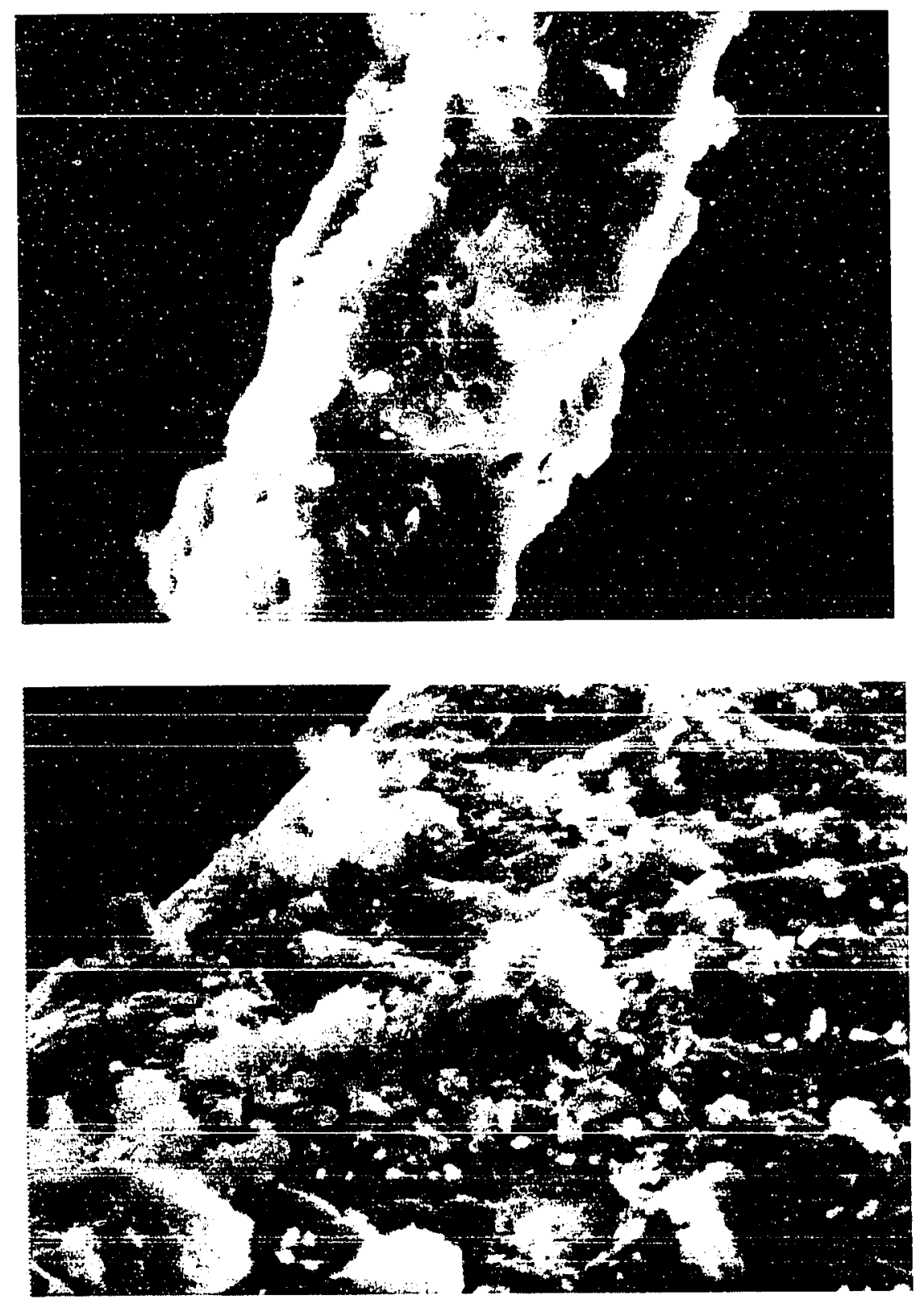

Fig. 9. Hair from a red-pelaged harbor seal was analyzed on a SEM. Hair tips (upper) and hair shafts (lower) had irregular cutical scaling and were coated with particulate matter. 

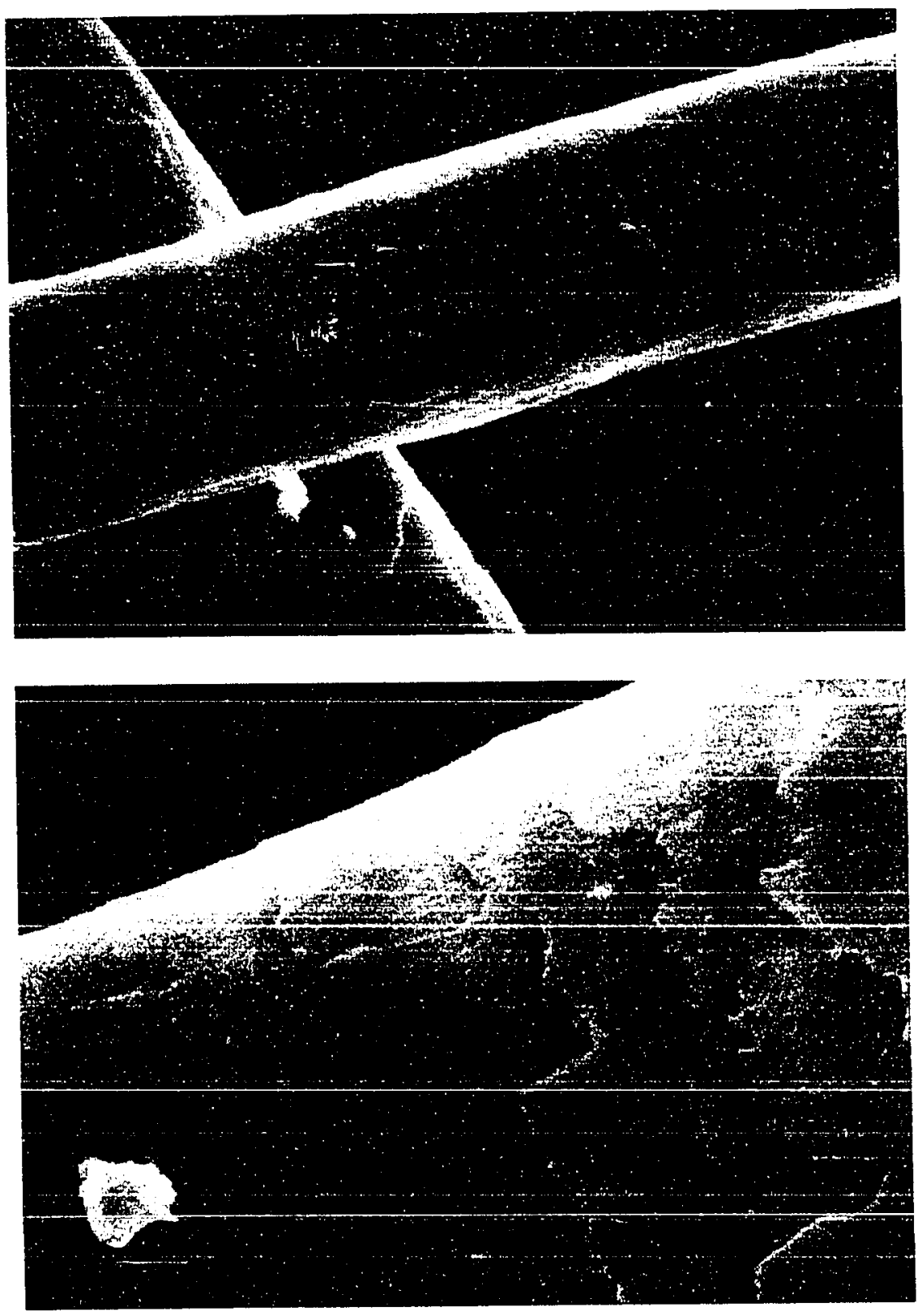

Fig. 10. Red-pelaged harbor seal hairs were stripped in ascorbate acid and analyzed on a SEM. Cutical scaling on hair tips (upper) and hair shafts (lower) had no cuticle scaling or particulate matter. 

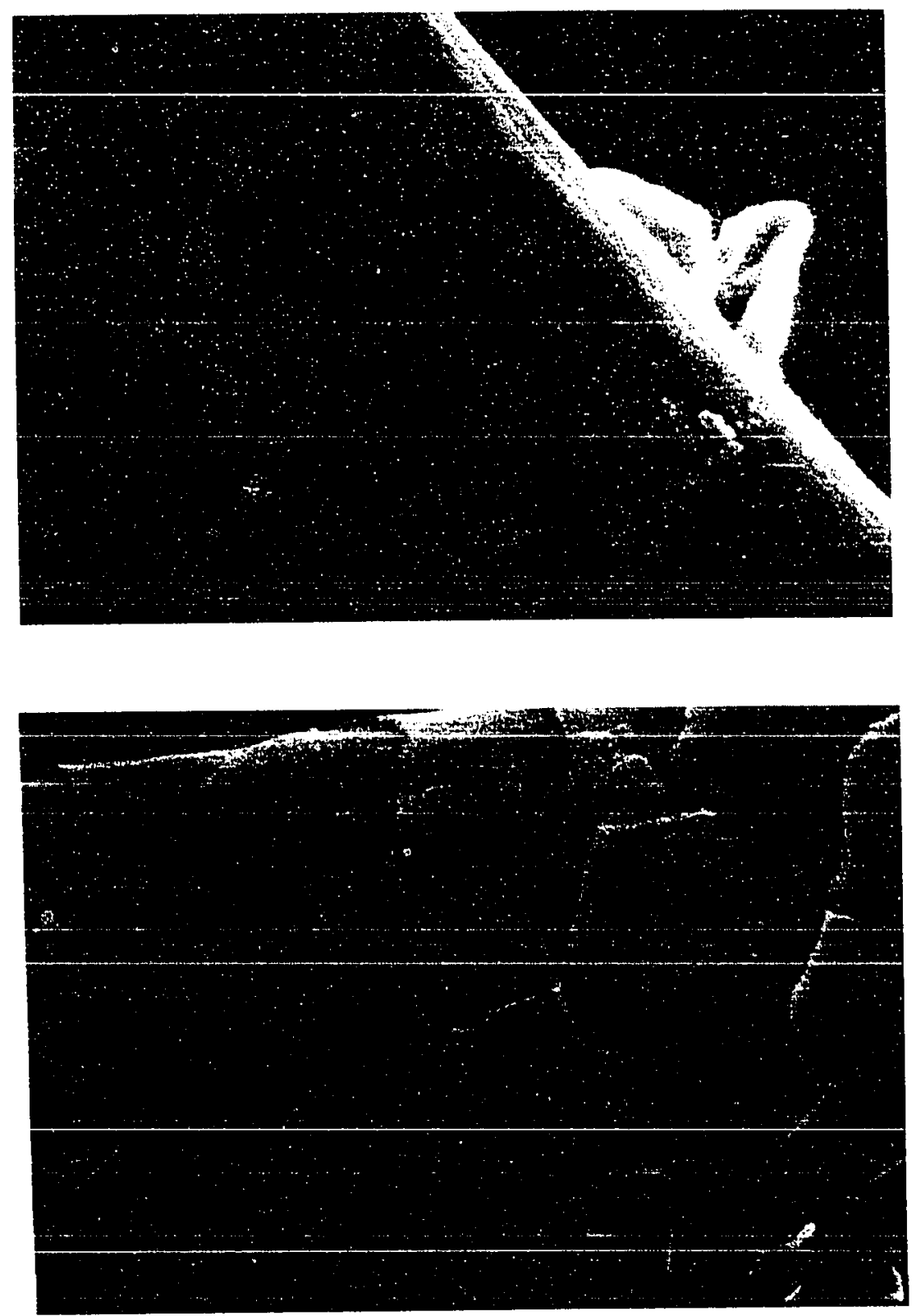

Fig. 11. Normal-pelaged harbor seal hair was stripped in ascorbate acid and analyzed on a SEM. Cutical scaling on hair tips (upper) and hair shafts (lower) had no cuticle scaling or particulate matter. 